\title{
Emerging Tools for Energy System Design Increasing Economic and Environmental Sustainability
}

\author{
Yee Van Fan ${ }^{1}$, Zorka Novak Pintarič ${ }^{2}$ and Jiří Jaromír Klemeš ${ }^{1, *(\mathbb{D}}$ \\ 1 Sustainable Process Integration Laboratory-SPIL, NETME Centre, Faculty of Mechanical Engineering, \\ Brno University of Technology_VUT Brno, Technická 2896/2, 61669 Brno, Czech Republic; fan@fme.vutbr.cz \\ 2 Faculty of Chemistry and Chemical Engineering, University of Maribor - UM FKKT, Smetanova ulica 17, \\ 2000 Maribor, Slovenia; zorka.novak@um.si \\ * Correspondence: klemes@fme.vutbr.cz
}

Received: 12 June 2020; Accepted: 30 July 2020; Published: 5 August 2020

\begin{abstract}
Energy is a fundamental element supporting societal development, particularly with the increasing dependency on the Internet of Things. It is also the main contributor to environmental impacts and subsequently, a potential sector for mitigation. Sustainable energy system design considers energy savings and energy efficiency, waste and consumption reduction, process efficiency enhancement, waste heat recovery, and integration of renewable energy. Emerging tools range from advanced Process Integration, modelling, simulation, and optimisation, to system analysis and assessment. This review covers selected emerging studies promoting sustainable system design, including the recent developments reported in the Special Issue (SI) of the 22nd Conference on Process Integration, Modelling and Optimisation for Energy Saving and Pollution Reduction (PRES'19). The primary emphasis was to enhance the economic and environmental performance. However, social factors were also highlighted as essential for future sustainable development. The discussion and analysis in this review focus on the most recent developments of (a) heat integration and heat transfer; (b) integrated and newly developed heat exchangers, (c) integration of renewables, and (d) roles in economic and environmental sustainability. The key results are highlighted, and future research ideas are suggested according to their links to a broader context.
\end{abstract}

Keywords: energy system; environmental sustainability; heat integration; economic sustainability; optimisation and modelling tools

\section{Introduction}

Energy is a fundamental social need and plays an essential role in driving economic growth. The emerging economy requires the support of a reliable, affordable, and energy system with low carbon emissions and air pollutants. Energy transition [1], process optimisation [2], efficiency enhancement, [3] and waste heat recovery [4] are the keys to support a sustainable energy system, especially when increasing energy consumption is unavoidable. There is no straightforward and absolute answer to sustainable design as various temporal [5], and spatial [6] factors have to be considered. The trade-off between the economic, environmental, and social factors remains an active research subject. The recently reported share of global renewable electricity generation by International Energy Agency (IEA) [7] is 26\%, dominated by solar photovoltaic (PV) followed by onshore wind and hydropower. Table 1 shows the greenhouse gas (GHG) and the water footprint of different energy sources. Some of the sources of renewable energy having a lower GHG footprint but a higher water footprint. The environmental performance of renewable energy cannot be concluded merely by the GHG or water footprint. The priority-GHG or water footprint reduction - and the selection of renewable energy is highly dependent on local conditions (e.g., resources). Involving the water-energy nexus complicates the issue further [8] because the water footprint consists 
of embodied energy. A more comprehensive sustainability assessment of different renewable energy sources is still needed to facilitate appropriate decision making. Non-renewable energy generally has a higher GHG and water footprint than that of renewable energy. However, it should also be noted that this footprint can be varied according to the technology, operation, and even the assessed life cycle boundary. Some of the most frequently implemented examples are biomass, where a large variation is reported [9], and biogenic carbon, which can significantly affect the estimated footprint [10].

The development of sustainable systems remains a challenge in reality due to the extensive range of economic, environmental, and social factors that have to be included during the system life cycle. It is important to ensure that sustainable system design is not transforming one problem into another problem. Comprehensive tools, methodologies, and assessment frameworks remain an on-going topic of research. Figure 1 shows the GHG and air pollutant performance related to the increased share of renewable energy in the European Union (EU). Although the $\mathrm{GHG}, \mathrm{NO}_{\mathrm{x}}$ and $\mathrm{SO}_{2}$, have decreased in line with reduced fossil fuel consumption, particulate matter (PM) and volatile organic compound (VOC) emissions have increased. More effort is required for a sustainable system design rather than focusing on solely questions of mitigating climate change or air pollution. Table 2 shows the levelized energy cost with and without subsidies and the changes in cost. The price of renewable energy has fallen significantly, particularly wind and solar energy, which are cheaper than non-renewable sources even without financial assistance. However, wind and solar are intermittent energy sources, which are not continuously available for conversion and available at every location. Lithium-ion batteries are the most competitive option with the highest potential for lifetime cost reduction [11], with the exception of long discharge applications. Based on a report by Lazard [12] considering the levelized cost of storage, solar PV with a storage system is economically attractive for short-duration wholesale and commercial use (102-139 USD/MWh) but remains a challenge for residential and longer-duration wholesale use (457-663 USD/MWh). Direct displacement of dispatchable energy sources by variable renewable energy can lead to cascade failures in the grid (blackouts) without consideration of flexible energy system design [13].

Table 1. The Greenhouse Gas (GHG) and water footprints of different energy sources.

\begin{tabular}{|c|c|c|c|}
\hline Energy Sources & $\begin{array}{l}\text { GHG Footprint } \\
\text { (kg/MWh) [14] }\end{array}$ & $\begin{array}{l}\text { Water Footprint } \\
\text { (L/MWh) [15] }\end{array}$ & Share of Water Footprint [16] \\
\hline Biomass & 45 & 85,100 & $\begin{array}{c}\text { 0.26\% Operation; negligible } \\
\text { Construction; } 99.73 \% \text { Fuel supply }\end{array}$ \\
\hline Hydropower & 26 & 4961 & $\begin{array}{l}\text { 100\% Operation; negligible } \\
\text { Construction; } 0 \% \text { Fuel supply }\end{array}$ \\
\hline PV & 85 & 330 & $\begin{array}{c}\text { 35.71\% Operation; } 64.29 \% \text { Construction; } \\
\text { 0\% Fuel supply c }\end{array}$ \\
\hline Wind & 26 & 43 & $\begin{array}{c}15.38 \% \text { Operation; } 84.62 \% \text { Construction; } \\
0 \% \text { Fuel supply }\end{array}$ \\
\hline CSP & $108.6^{\mathrm{a}}[17]$ & 1250 & $\begin{array}{c}35.71 \% \text { Operation; } 64.29 \% \text { Construction; } \\
0 \% \text { Fuel supply c }\end{array}$ \\
\hline Geothermal & $53^{\mathrm{b}}[18]$ & 1022 & $\begin{array}{c}99.39 \% \text { Operation; } 0.61 \% \text { Construction; } \\
0 \% \text { Fuel supply }\end{array}$ \\
\hline Oil & 735 & 3220 & $\begin{array}{l}\text { 88.70\% Operation; negligible } \\
\text { Construction; } 11.1 \% \text { Fuel supply }\end{array}$ \\
\hline Nuclear & 28 & 2290 & $\begin{array}{l}\text { 89.93\% Operation; negligible } \\
\text { Construction; } 10.03 \% \text { Fuel supply }\end{array}$ \\
\hline Coal & 888 & 2220 & $\begin{array}{l}\text { 89.93\% Operation; negligible } \\
\text { Construction; } 10.03 \% \text { Fuel supply }\end{array}$ \\
\hline Natural Gas & 500 & 598 & $\begin{array}{l}97.13 \% \text { Operation; } 0.45 \% \text { Construction; } \\
2.43 \% \text { Fuel supply }\end{array}$ \\
\hline
\end{tabular}

PV = photovoltaic; CSP = concentrated solar power. The GHG footprint is based on the reported study in [14] except for CSP ${ }^{a}$ and geothermal ${ }^{b}$. ${ }^{c}$ The share of water footprint reported in [16] for solar power is not specified by the type of technology. 


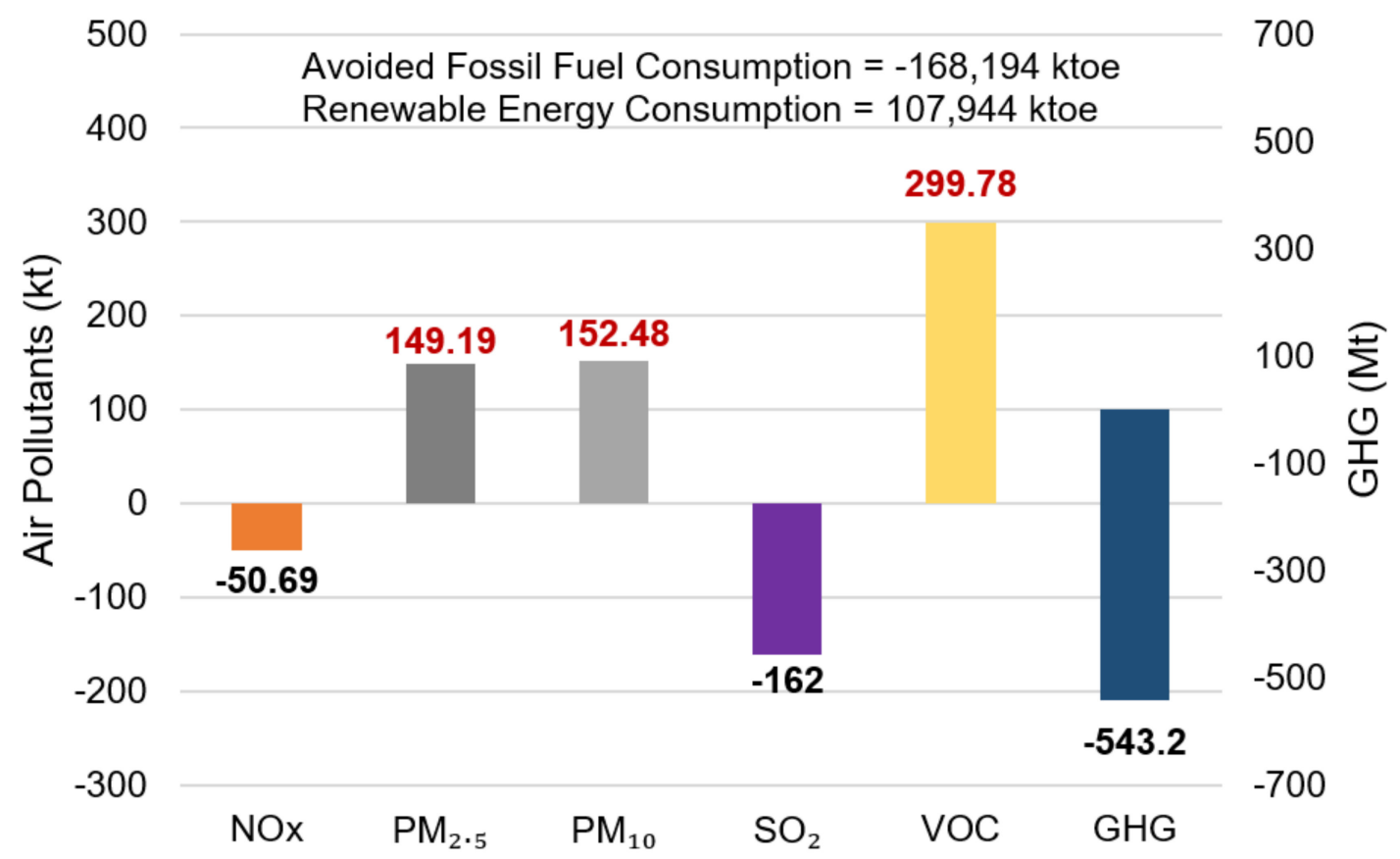

Figure 1. The changes in GHG and air pollutant performance with an increasing share of renewable energy (comparison between 2005 and 2018). Data extracted from [19].

Table 2. The levelized energy cost of different sources. ${ }^{a}$ The considered subsidies are based on US federal tax subsidies which can vary from country to country. ${ }^{b}$ Biomass is based on the analysis of Version 11.0 [20] because there is no related information in Version 12.0 [21].

\begin{tabular}{|c|c|c|c|}
\hline Energy Sources & $\begin{array}{l}\text { Levelized Energy Cost } \\
\text { (USD/MWh) [21] }\end{array}$ & $\begin{array}{l}\text { Without Subsidies } \\
\text { (USD/MWh) [21] }\end{array}$ & $\begin{array}{c}\text { Changes in Cost (\%) [22] } \\
\text { Global Weighted-Average LCOE }\end{array}$ \\
\hline Solar PV & $32-245$ & $36-267$ & $\begin{array}{c}-77 \% \\
(0.085 \mathrm{USD} / \mathrm{kWh})\end{array}$ \\
\hline CSP & $96-169$ & 98-181 & $\begin{array}{c}-45.75 \% \\
(0.185 \mathrm{USD} / \mathrm{kWh})\end{array}$ \\
\hline Geothermal & $67-110$ & 71-111 & $\begin{array}{c}+50 \% \\
(0.072 \mathrm{USD} / \mathrm{kWh})\end{array}$ \\
\hline Wind & $14-47$ & $29-56$ & $\begin{array}{c}-20-34 \% \\
\left(0.127^{\mathrm{a}}-0.045 \mathrm{USD} / \mathrm{kWh}\right)\end{array}$ \\
\hline Biomass & $40-112^{b}$ & $55-114^{b}$ & $\begin{array}{c}-17.33 \% \\
(0.062 \mathrm{USD} / \mathrm{kWh})\end{array}$ \\
\hline Nuclear & $112-189$ & NA & NA \\
\hline Coal & $60-143$ & NA & NA \\
\hline
\end{tabular}

Fikse et al. [23] stated that traditional system engineering practices attempt to anticipate disruptions; however, they may be susceptible to unforeseen factors. This is particularly reflected in the unexpected outbreak and impact of COVID-19. The disease threatens human life while also serving to highlight existing or potential vulnerabilities of emergency responses and various system designs (i.e., capacity, allocation, and flexibility). A sustainable system design with inherent resilience would likely be valuable in future research. One of the apparent crises during COVID-19 is the shortage of personal protective equipment, particularly in countries reliant on international production. Global value chains may be reconsidered after the COVID-19 outbreak, as suggested by Kambhampati [24], due to the profound risk they pose. COVID-19 has also had an influence on the energy system. Figure 2 shows the supplies of minerals that support energy production. In addition to $\mathrm{Cu}, \mathrm{Li}, \mathrm{Co}$, and $\mathrm{Ni}$, renewable energy used $\mathrm{Si}, \mathrm{Zn}, \mathrm{Mo}$, and rare earth minerals, which are non-renewables. It has been reported that electric cars use five times more minerals than a conventional car, and onshore wind plants require eight times more minerals compared to gas-fired plants [25]. As shown in Figure 2, the production 
of $\mathrm{Si}, \mathrm{Zn}, \mathrm{Mo}$, and rare earth minerals is dominated by China. The reliability, security, and price fluctuations of mineral supplies is an under-analysed global challenge in the promotion of a $100 \%$ renewable energy future.

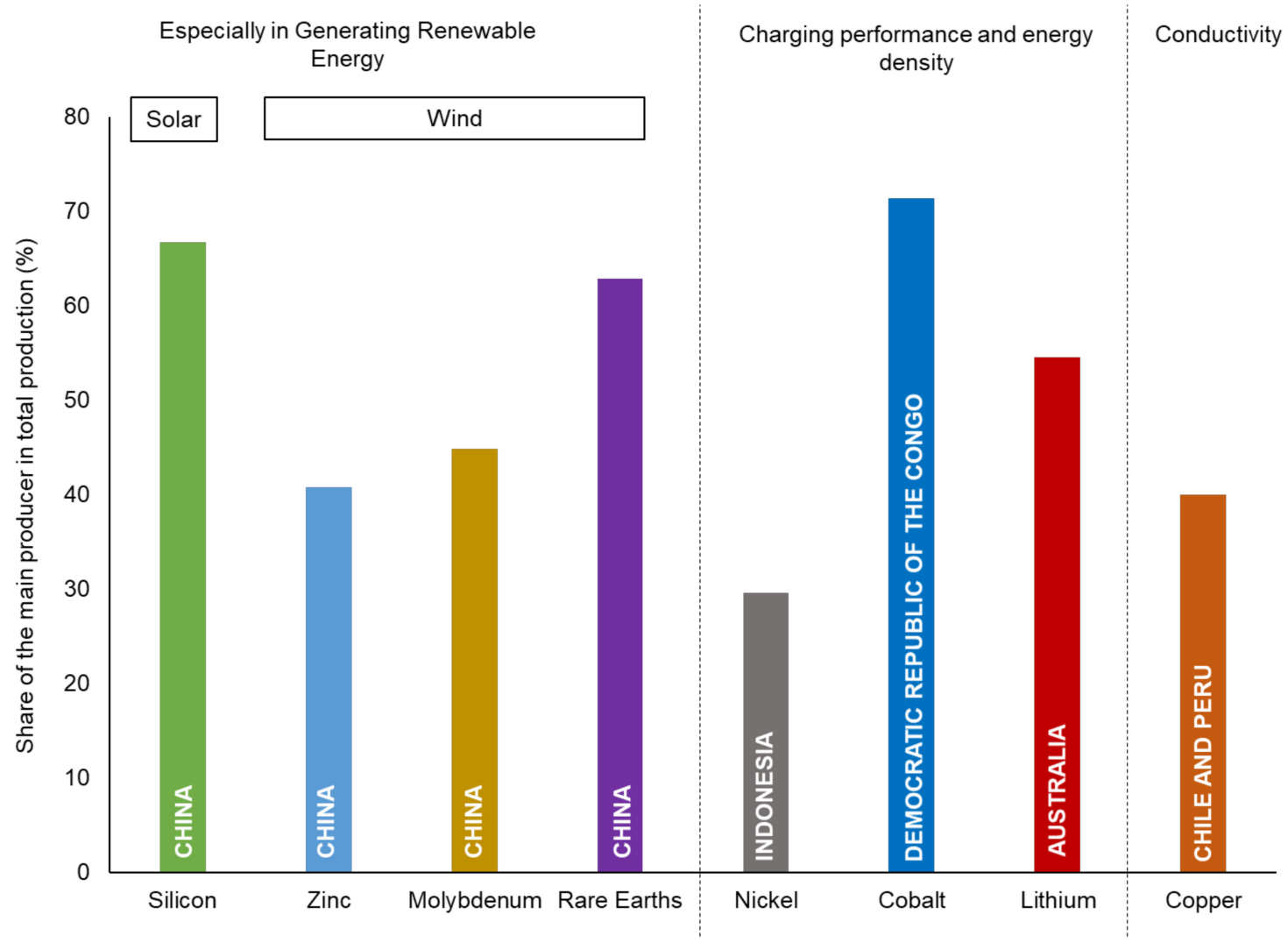

Figure 2. Supplies of minerals that support energy production. Information collected from [25], except for zinc [26] and silicon [27].

Figure 3 shows the structural changes and impacts of energy demand during movement restriction. Domestic electricity demand has generally increased, and there has been a shift in the timing of peak demand during the middle of the day. The reduction of electricity demand in selected countries has also been reported by IEA [28]. The fall in overall electricity consumption is due mainly to the shutdown of industry, and the share of renewable energy has been reported to have increased. The temporary impacts are generally favourable where the consumption and environmental footprint is reduced. However, IEA [29] highlighted that the energy industry that emerges from COVID-19 would change significantly, particularly given an expectation of a reduction in investment. This could inhibit sustainable development because energy is likely to be affected first. In Germany, the pandemic has led to a decrease in power demand and negative electricity prices. Amelang [30] highlighted that negative rates have no benefit to consumers as the difference between negative power prices and the feed-in tariffs ultimately have to be paid. Oversupply reflects inefficiency and highlights a need for a better demand response and flexible renewables design. Positively, however, this crisis has highlighted a weakness and represents an opportunity to steer system design research onto a more resilient, secure, and sustainable path. 

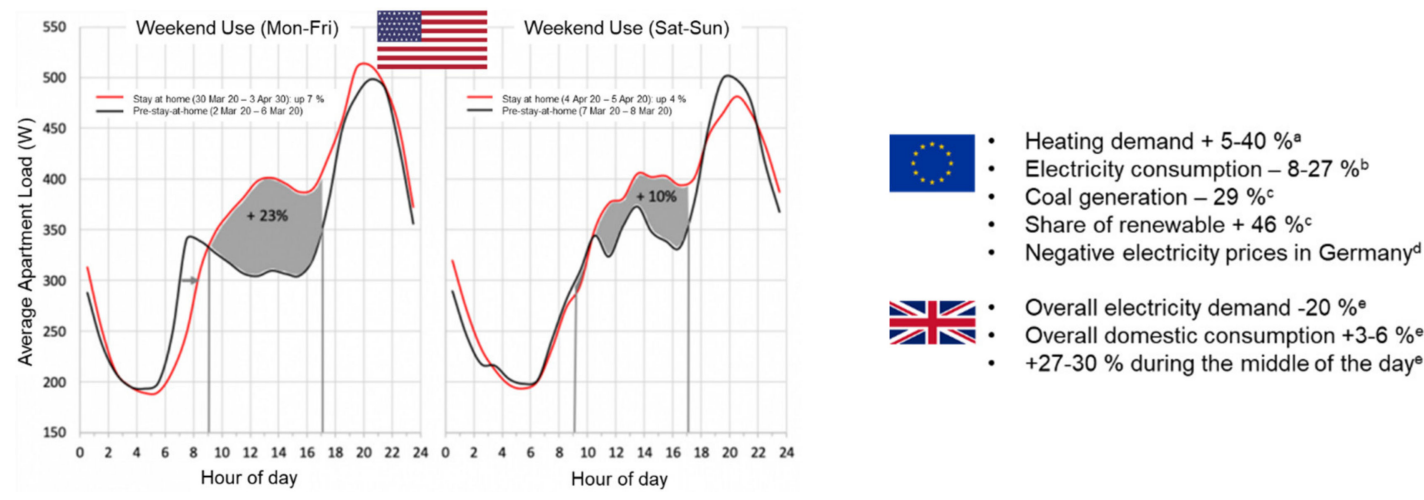

Figure 3. The structural changes and impacts of energy demand during movement restriction of COVID-19 in New York City [31], the European Union [32] ${ }^{\mathrm{a}}[33]^{\mathrm{b}}[34]^{\mathrm{c}}[30]^{\mathrm{d}}$, and the UK [35] ${ }^{\mathrm{e}}$.

The circular economy approach has undergone substantial development and increasingly used as a framework for system energy design, assessment, and implementation at various levels, beginning with production plants, through municipal and governmental strategic plans. Korhonen et al. [36] is one contributor who highlighted the need for scientific research into the quantification of actual environmental impacts. This is because a highly implemented circular economy progresses toward sustainability features. However, some of the circularity features (e.g., reprocessing waste) can be energy-intensive. Another work by Kirchherr et al. [37] emphasised that a potential variety of the circular economy concept which is complemented with a lack of quantification, if not fully based on a footprint strategy, can result in a conceptual deadlock. Table 3 summarises the six circular strategies consisting of the 9Rs (Refuse, Rethink, Reduce, Reuse, Refurbish, Remanufacture, Repurpose, Recycle, Recovery) practices with quantitative/qualitative indicators. A set of indicators comprising scale indicators and the circularity rate (\%), and covering socioeconomic cycling, ecological cycling potential, and non-circularity, has also been proposed by Mayer et al. [38] for the EU. The proposed indicators can be considered to be relatively comprehensive. However, they serve mainly as a monitoring framework (system assessment tools) rather than a system engineering model.

Table 3. Circular economy strategy and its indicators. Extracted from [39].

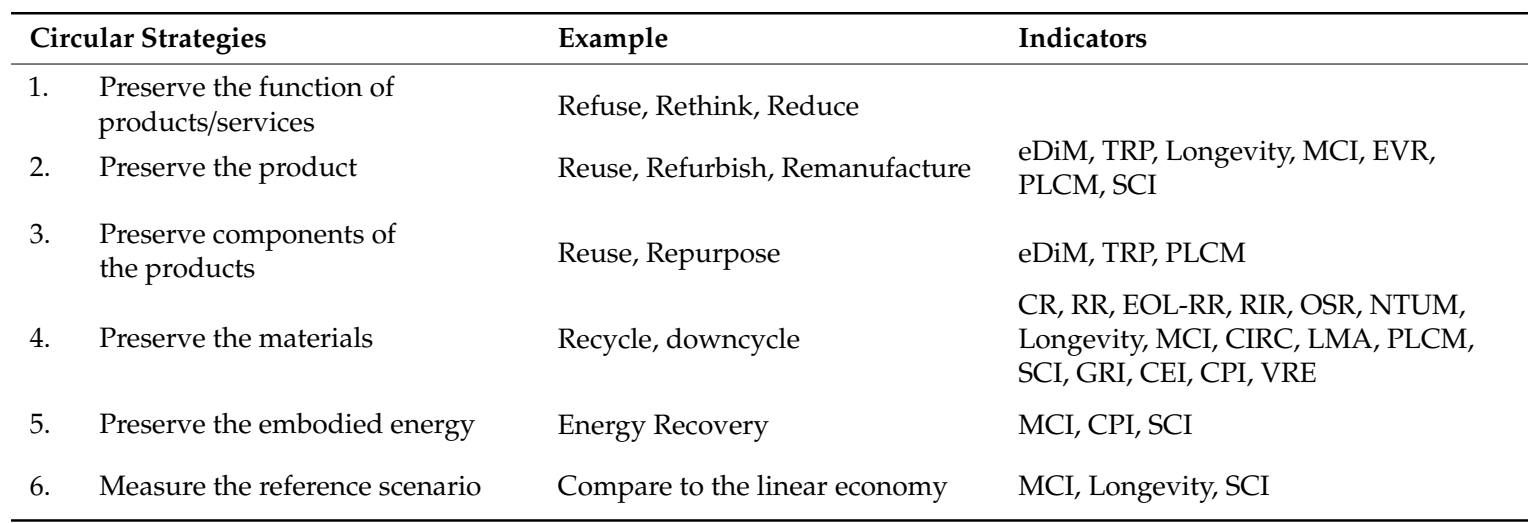

$\mathrm{eDiM}=$ Ease of disassembly metric, TRP = Total restored product, $\mathrm{MCI}=$ Material circularity metric, EVR = Eco-cost value ratio, $\mathrm{PLCM}=$ Product-level circularity metric, $\mathrm{SCI}=$ Sustainable circular index, $\mathrm{CR}=$ Old scrap collection rate, $\mathrm{RR}=$ Recycling process efficiency rate, EOL-RR $=$ End of life recycling rate, $\mathrm{RIR}=$ Recycling input rate, OSR = Old scrap ratio, NTUM $=$ Number of times use of a materials, CIRC $=$ Material circularity indicator, LMA $=$ Lifetime of materials in anthroposphere, GRI = Global resource indicator, $\mathrm{CEI}=$ Circular economy index, $\mathrm{CPI}=$ Circular economy performance indicator, VRE = Value-based resource efficiency.

System design is important in facilitating sustainable development. Various works that aspire to promote sustainable system design by addressing the issues of enhancing energy and environmental performance were presented in the Special Issue (SI) of the 22nd Conference on Process Integration, Modelling and Optimisation for Energy Saving and Pollution Reduction (PRES'19). The aim of this 
study is to review the emerging tools for sustainable system design, including the recent developments reported in the Special Issue (SI) of PRES 2019. The energy system design tools that are considered in this study are summarised in Figure 4, including modelling, simulation, optimisation, and analysis or assessment.

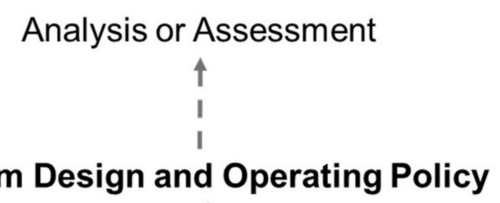

\section{System Design and Operating Policy}

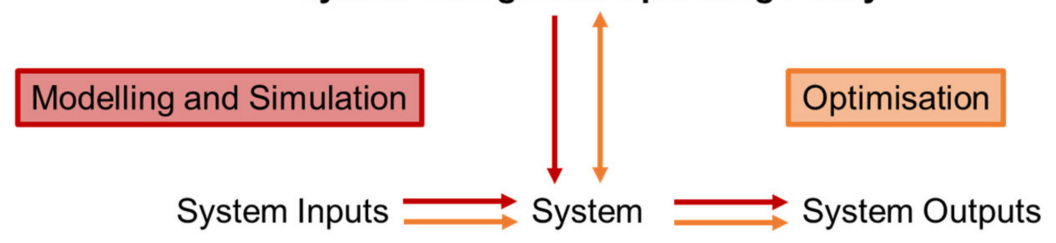

Figure 4. The research direction of sustainable system design. Modified based on Loucks [40]. The considered tools reviewed in this study include those used for modelling and simulation, optimisation, and analysis or assessment, that can contribute to energy system design. Red arrows represent modelling and simulation. Orange arrows represent optimisation. The grey arrow represents analysis or assessment. For example, modelling and simulation utilise system inputs and the available system design and operating policy to identify the system outputs. Analysis or assessment is conducted to determine the performance of an existing system.

The papers are categorised into four topics in Section 3, focused on modelling, simulation, optimisation, and assessment studies on the topics of:

a. Heat Integration and heat transfer.

b. Integrated and newly developed heat exchangers.

c. Integration of renewables.

d. Roles in economic and environmental sustainability.

\section{Emerging Tools}

This section discusses the modelling, simulation, optimisation, and assessment studies aimed at improving heat integration and heat transfer, integrated and newly developed heat exchangers, integration of renewables, and economic and environmental sustainability. One-third of energy is lost in the form of waste heat, as reported by [41]. According to the analysis by Papapetrou et al. [42], the total waste heat potential in EU is about $300 \mathrm{TWh} / \mathrm{y}$, of which one-third is low-temperature waste heat, $25 \%$ occurs between $200-500{ }^{\circ} \mathrm{C}$, and the remainder occurs above $500{ }^{\circ} \mathrm{C}$. Bianchi et al. [43] suggested the theoretical potential of the EU's thermal energy waste was $920 \mathrm{TWh} / \mathrm{y}$ and $279 \mathrm{TWh}$ of Carnot potential. This highlight the important roles of waste heat recovery in enhancing energy efficiency and emission reduction.

Heat integration [44] and heat transfer intensification [45] are long-standing tools for reducing energy consumption. However, they are continuing to be valuably extended. They have supported a significant issue, namely the reduction of the cost of energy transmitted to the cost of products and services. A substantial amount of effort has been made in making energy cleaner. However, the cleanest energy is that saved and consequently not produced [46]. These issues are closely related to environmental footprints, particularly carbon footprints. These should more precisely be named carbon emissions footprints and, more comprehensively, greenhouse gas footprints, including other greenhouse gases in addition to $\mathrm{CO}_{2}$ [47]. The most important is, in addition to $\mathrm{CO}_{2}, \mathrm{CH}_{4}$ and water vapour. To a lesser extent, but still significant, are surface-level ozone, $\mathrm{NO}_{\mathrm{x}}$, and fluorinated gases, because all of these also involve infrared radiation [48]. 
However, all of the mentioned tools would not be possible without heat exchangers [49]. Heat exchangers are an important component in most plants, and they are also used in motor vehicles and airplanes. Their efficiency and cost-to-energy-saved ratio are important for their value to modern design. They have been continuously developed from their advent during the industrial revolution until the highly sophisticated pieces of equipment of the present [50]. A notable development comprises a modern plate and compact heat exchangers performing at low $\Delta \mathrm{Tmin}$, which are able to reduce low potential waste heat. In Northern China, for example, this amounts to $100 \mathrm{Mt}$ standard coal equivalents (Mtce, $2.93 \mathrm{EJ}$ ) and throughout steel mills in Hebei province it reaches 44,268 MW and in cement factories $2155 \mathrm{MW}$ [51]. These issues were addressed by several papers in the SI, e.g., [52].

Renewables implementation remains a challenge despite the fact that their economic feasibility is reported to be improving (see Section 1). The technical challenges encountered arise mainly from the reliability of supply, facilities for transmission and distribution networks, connectivity to the existing grid, and storage. Modelling and simulation studies facilitate the understanding of the energy system (time profile scale and uncertainty, conditions, limitations) and predict performance in the real world for a more reliable integrated design. Different methods exist to address renewable uncertainty, for example, stochastic programming, fuzzy theory, robust programming, chance-constrained programming [53] and point estimate method [54]. Mehrjerdi and Rakhshani [55] modelled the correlation of time scale and uncertainty in an energy management system and incorporated load and wind energy uncertainties using mixed-integer stochastic programming. Talaat et al. [56] integrated wave, solar, and wind energy in a study in which the change of different environmental conditions was considered via simulation using Simulink. Baum et al. [57] assessed the intermittency mitigation potential of a dynamic, active demand response method in a smart grid using Monte Carlo simulation. Simulation software for a power system using intermittent energy sources was demonstrated by Fiedler [58] based on weather data in Australia. The advantages of diversification compared to dependence on a mono-system were highlighted. Draycott et al. [59] reviewed approaches to replicating the ocean environment, which is relatively complex, for an offshore renewable energy simulation (physical and numerical). Conducting such simulations is important prior to costly full-scale wave, tidal energy development. Long-range energy alternatives planning system (LEAP) and MARKAL simulations have also been used as forecasting models in various energy planning studies [60].

Optimisation studies of renewable energy are relatively broad, and coverage can range from micro (efficiency, material) to macro (regional planning, distribution design) aspects. An example of optimisation studies from a micro perspective is the optimisation of biomass blends for syngas production [61]. To enhance the energy efficiency of solar PV panels, Peng et al. [62] optimised their cooling performance and suggested the efficiency enhancement is up to 47\%. Bravo et al. [63] assessed the integration of the calcium looping process as a thermochemical energy storage system in hybrid solar power plants. Macro-level optimisation focuses on distribution planning or design. For example, Zheng et al. [64] optimised the design of a biomass integrated microgrid with demand-side management under uncertainty. Nowdeh et al. [65] proposed a method based on a multi-objective evolutionary algorithm to optimise the placement and sizing of photovoltaic panels and wind turbines in a distribution network. A similar study was conducted by Jafari et al. [66], but the objective function was to minimise pollution, financial, and reliability issues rather than to reduce loss and improve reliability. Rinaldi et al. [67], in contrast, optimised the allocation of PV and storage capacity considering consumer types and urban settings for Switzerland. Another stochastic mathematical model was proposed by Santibañez-Aguilar et al. [68] to specifically support PV manufacturing supply chain development. It is crucial to support overall sustainability by considering the potential to locally produce different PV elements. Because flexibility is an important element of an integrated renewable energy system, stochastic optimisation algorithms are one of the most commonly applied methods [69]. The Fuzzy -graph is another method that can be applied to optimise renewable energy utility systems, as used by Aviso [70] for the abnormal operation of an off-grid system. Various software tools for the planning of hybrid renewable energy systems, including HOMER, Calliope, RETScreen, DER-CAM, Compose, iHOGA, and EnergyPRO, 
were recently reviewed by Cuesta et al. [71]. Akhtari et al. [72] optimised hybrid renewable earth-air heat exchanger with an electric boiler, wind, PV, and hydrogen configuration and Amin Razmjoo et al. [73] optimised a distributed generation-based photovoltaic system using HOMER. The inclusion of social factors in software tools is suggested to further enhance the capability of the software packages in optimising design.

Analysis and assessment studies can act as monitoring tools to determine the current performance quantitatively for comparison between alternatives and identify possible improvements in design. Life cycle assessment (LCA) based on environmental impacts or environmental footprints [47] and techno-economic assessment [74] are among the common approaches. Khoshnevisan et al. [75] performed a consequential life cycle assessment to compare the conversion of the organic fraction of municipal solid waste to bioenergy and high-value bioproducts (e.g., microbial protein, lactic, and succinic acid). The environmental impact of energy production through anaerobic digestion of pig manure was quantified by Ramírez-Islas [76]. Eutrophication was identified as the most negative effect which required further attention. To simplify the LCA of solar heating and cooling technologies, Longo et al. [77] developed an Environmental Lifecycle Impacts of Solar Air-conditioning System (ELISA) tool to account for the energy and environmental impacts. The PV-assisted system was identified as having a better life cycle performance compared to thermal-driven solar heating and cooling and a conventional system (electric heat pump). Wang et al. (2020) identified the geothermal gradient as the key factor of environmental impacts, in which acidification, eutrophication, and global warming potential can be reduced by a large geothermal gradient. Life cycle sustainability assessment [78] has received increasing attention in recent years. This is similar to LCA, but more comprehensively represents sustainability, including consideration of social life cycle assessment and life cycle costing. Because of increasing concern regarding interrelationships, nexus analysis has been conducted to further understand sustainability, particularly relating to the water-energy nexus, as conducted by Duan and Chen [79]. Fan et al. [80] proposed a graphical analysis tool considering the emission-cost nexus for sustainable biomass utilisation. Various sustainability indicators have also been developed for decision making, e.g., sustainable energy development index [81] and other sustainability indicators for renewable energy systems reviewed by Liu [82].

\section{Issues Developed and Extended in this Special Volume}

\subsection{Heat Integration and Heat Transfer}

The first paper on this subject, entitled "Thermal Effects of Natural Gas and Syngas Co-Firing System on Heat Treatment Process in the Preheating Furnace" and authored by Jóźwiak et al. [83], examined the possibilities of partially replacing natural gas with synthesis gas derived from biomass. The system under study was a preheating furnace in the steel industry, for which the authors investigated how the air volume, the distribution of burner power, and the share of bio-based gas influenced heat transfer, temperature, and gas flow in the furnace. The modelling was performed with a computational fluid dynamics tool. Computational fluid dynamics (CFD) tools are widely used to simulate and optimise the processes of heat transfer [84] and energy release from various fuels [85]. The results showed that up to $40 \%$ of the natural gas could be replaced by syngas of biogenic origin, while still achieving satisfactory thermal efficiency and temperature characteristics. The authors claimed that GHG emissions could be reduced by $40 \%$. The results showed that the replacement of fossil fuels by renewable fuels needs to be promoted, especially in heat-intensive industrial plants, as satisfactory operational performance can be achieved with significantly lower emissions. However, the economic performance also needs to be analysed and taken into account because renewable fuel production processes are not yet necessarily economically viable; see You et al. [86].

The next paper, "Isomerisation of n-C5/C6 Bioparaffins to Gasoline Components with High Octane Number", authored by Hancsók et al. [87], addresses the challenges of producing fuels from alternative sources such as waste and biomass. These fuels often contain by-products, e.g., light hydrocarbons, 
especially n-alkanes C5-C7, which reduce the quality and negatively affect the safety properties of the fuel. Light hydrocarbons are formed in the production of bio-gasoline from rice straw biomass [88], Fischer-Tropsch synthesis of syngas from wood chips [89], and in various chemical reactions involving sorbitol [90] and simple sugars [91]. Catalytic reactions of isomerisation and aromatisation were carried out in the experimental device, in which light hydrocarbons were converted into iso-alkanes with a higher octane number. The authors claimed that the yield of liquid products could exceed $98 \%$, and the research octane number could reach 92. Improved reaction pathways and optimised operating conditions for high quality, affordable, and safe end products could facilitate the success of fossil fuel replacements.

One of the measures to increase energy efficiency is to improve heat transfer between fluids in heat exchanger units. The authors of the next paper, Tian et al. [92], entitled "Numerical Study of Heat Transfer in Gravity-Driven Particle Flow around Tubes with Different Shapes", investigated the mechanism of heat transfer in moving bed heat exchangers, in which heat transfer takes place between the solid particle stream and the fluid. This type of heat exchanger is widely used in energy-intensive industries. The influence of tube shape, particle outlet velocity, and diameter on particle movement and heat transfer efficiency were investigated. Modelling was performed for five different geometric tube shapes, such as circular, elliptical, and flat elliptical, using the discrete element method [93]. The model was validated by comparing the authors' results with experimental results from the literature [94]. The main contribution of the research was the visualisation of heat transfer parameters and solid particle motion for different tube shapes. The particle velocity distribution around the tubes, the contact time of the particles with the tube, and the heat transfer coefficient as a function of the output velocity of the particles were presented. The heat transfer coefficient was also influenced by the particle size; the smaller the particles, the higher the value of the coefficient. The authors concluded that the elliptical tube was best suited for use in moving bed heat exchangers as it demonstrated the best particle motion and heat transfer properties.

The next article, authored by Létal et al. [95] and entitled "Nonlinear Finite Element Analysis-Based Flow Distribution and Heat Transfer Model", also dealt with fluid flow and heat transfer in large heat exchangers in the process and energy industry. The CFD method, which can be very computationally intensive, is most often used to model various types of heat transfer units, such as compact heat exchangers [96], cross-flow heat exchangers with elliptical tubes [97], or plate solar collectors [98]. In this paper, a simplified model using the finite element method was developed. The model calculated outlet temperatures and pressure drops on the pipe side and the shell side. It was able to handle the laminar and turbulent flow. The model was used for two types of heat exchangers. The results were compared with data from the literature [99], with the results of a commercial computer program [100] and with data from an existing energy plant. Visualisations of temperature profiles for hot and cold streams, in addition to fluid velocities within the exchanger, were presented. The authors argued that their program was easier to use than the commercial program and provided comparable results with less computational effort. They noted that the model still needs to be validated and improved to predict the mechanical stresses that could occur due to uneven thermal loads, which could also result in mechanical failures.

In the next paper, "Comparison of the Evaporation and Condensation Heat Transfer Coefficients on the External Surface of Tubes in the Annulus of a Tube-in-Tube Heat Exchanger", the authors, Tang et al. [101], investigated the influence of the tube surface in a heat exchanger on the efficiency of heat transfer. They compared a tube with a smooth surface and a tube in which the dimples were arranged along the surface in a certain pattern. Several studies conducted in the past have shown that dimpled tubes provide better heat transfer than smooth tubes [102]. However, it was also observed that heat transfer in smooth tubes was better when the refrigerant was condensed on horizontal tubes [103]. Investigations were conducted using an experimental unit with a double-pipe heat exchanger, in which the evaporation and condensation of the refrigerant took place in the intermediate space (the so-called annulus). The influence of mass velocity, annulus width, and steam quality on the heat transfer 
coefficient was measured. The results showed that the heat transfer coefficient increases with mass velocity in both types of tubes. Compared to a smooth tube, the tube with a modified surface showed significantly improved heat transfer during fluid condensation. A slight improvement was also observed in the case of boiling under certain conditions, while under other conditions a smooth tube proved to be better. It was concluded that the modified surface used in the study could be suitable to improve heat transfer during condensation of fluid, but not to enhance the wave-like stratified flow during boiling.

In the last paper on this topic, the authors Gai et al. [104] reported on the "Critical Analysis of Process Integration Options for Joule-Cycle and Conventional Heat Pumps". They examined different types of heat pumps and their heat integration into the process. The analysis included traditional heat pumps, such as the vapour compression heat pump (VCHP) [105] and the transcritical heat pump (TCHP) [106], in addition to a newer Joule cycle heat pump (JCHP) [107]. The aim was to determine which type of heat pump was more suitable for a specific process. The operation of heat pumps was simulated with the Petro-SIM program. To investigate the integration of the heat pump into the process, the authors used the pinch method, in particular the Grand Composite Curve. Four case studies from the food and chemical industry were analysed. The results demonstrated that the slopes of the source and sink curves in the temperature-heat flow diagram were most important for the selection of the most suitable heat pump. If the source and sink process curves are steep, it is advantageous to choose a JCHP that has a low average temperature difference of the working fluid and the source/sink. Its Coefficient of Performance (COP) is consequently higher. For processes with flat sink and source process curves, $\mathrm{VCHP}$ is more favourable. The smaller the difference between the inlet temperatures of the sink and the source, the higher is COP with this type of heat pump. The use of TCHP is limited to processes where the slope of the source is relatively small, and the slope of the sink is relatively large. The advantage of the approach proposed is that it allows a quick selection of a suitable heat pump based on the temperature-enthalpy diagram for a particular process.

\subsection{Integrated and Newly Developed Heat Exchangers}

Wang et al. [108], in their paper entitled "An Extended Grid Diagram for Heat Exchanger Network Retrofit Considering Heat Exchanger Types", developed a new approach to heat exchanger network retrofit that determines the retrofit design and selects the most cost-effective heat exchanger types. It targeted some specific features, as noted in a recent review [49]. The approach is based on the pinch method and uses the visualisation of an extended grid diagram previously developed by Yong et al. [109] to identify possible alternatives for improving the network. The method developed for this Special Issue allows choosing between six common industrial types of heat exchangers and estimates their capital cost. In addition to graphical methods, mathematical programming (MP) can also be used for a similar purpose, as shown by Soršak and Kravanja [110], who developed a mathematical model for network synthesis including the selection of heat exchanger types. However, as the presented paper demonstrated, selection of heat exchanger types for the retrofit should consider that the temperatures of the process streams should be within the temperature ranges applicable for each of the six types of heat exchangers. For this reason, the calculated heat transfer area is required to be within the recommended area range of the specific exchanger type. For the identified alternative retrofit plans, the investment in heat exchangers and the utility cost were assessed, and the optimum retrofit design was selected. The implementation of the proposed methodology to a network with six hot and one cold streams was presented based on the problem presented by Yong et al. [111]. The SRTGD-STR (Shifted Retrofit Thermodynamic Grid Diagram with the Shifted Temperature Range of Heat Exchangers) appears to provide valuable visualisation, representing a considerable advantage compared to MP for retrofitting heat exchanger networks (HENs). A reduction in utility cost was achieved, while the right choice of heat exchanger typed enabled relatively low investment cost.

In the next article, written by Langner et al. [112] and entitled "A Framework for Flexible and Cost-Efficient Retrofit Measures of Heat Exchanger Networks", the design of a retrofitted heat exchanger 
network was discussed, taking into account uncertain input data. Uncertainty is an important aspect that influences the flexibility of the network, which should operate optimally even with fluctuating input data. The design of processes under uncertainty conditions is a significant challenge because a process model must be solved for several scenarios at the same time [113]. The presented model was extensive, and the computational effort for its solution can be high. Langner et al. [112] proposed a multi-step methodology in which they reduced the complexity of the problems they addressed in each step. The application of the methodology was demonstrated using the example of a network with two hot and two cold streams and eight uncertain parameters, i.e., related to inlet temperatures and heat capacity flow rates. The procedure started with the initial structure of the network, for which several reconstruction proposals were derived using graphical methods, with the aim of reducing the consumption of the hot utility. The flexibility of the given retrofit proposals was checked, and alternatives that did not reach the required value of the flexibility index were rejected. For feasible alternatives, critical points were determined using methods from the literature [114]. By considering critical points, a multi-period optimisation mixed-integer nonlinear programming (MINLP) problem that selects the network retrofit proposal with the lowest total annual cost was solved. Finally, the flexibility of the selected solution was reviewed. In the proposed methodology, graphical methods to generate alternative retrofit proposals and mathematical programming methods to select an optimal design of heat exchanger network were combined. They improved and automated the procedure for determining critical points. The authors suggested that their methodology could be suitable for retrofitting larger industrial networks.

The synthesis of heat exchanger networks (HENs) is usually performed separately from utility system design. The authors of the third article within this topic, Sheng et al. [115], pointed out the advantage of simultaneous synthesis of a heat exchanger network and a steam generation system in their paper entitled "Simultaneous Synthesis of Heat Exchanger Networks Considering Steam Supply and Various Steam Heater Locations". The steam generation system was based on the Rankine cycle, which generates multi-level saturated and superheated steam, and the power [116]. The authors of this SI paper chose a multi-stage superstructure of a HEN as a basis, which they combined with a utility system. The mathematical model of a composite system corresponded to the MINLP optimisation model, which contained mass and energy balances, feasibility constraints for the temperature and utility system, and an objective function based on the total annual cost. Binary variables were used to select the heat matches; continuous variables represented temperatures, heat flows, surface areas of heat exchangers, amounts of generated steam, and power. The developed model was illustrated using a case study with four hot and four cold streams connected to a Rankine steam system. The selection of multi-level steams and their use at the end of the streams and/or between the stages allowed greater flexibility in optimising steam distribution, power generation, and fuel consumption. Better economic parameters of the overall system can be achieved. The simultaneous synthesis of the network and the utility system makes it possible to establish interactions between the investments, the fuel cost, and the revenues from the electricity generated, leading to better solutions than if the two systems were considered separately.

Haber-Bosch ammonia synthesis is a well-established mature technology, but is still a challenge due to the demanding operating conditions and the highly exothermic reaction that requires an efficient heat transfer system. Processes for the synthesis of ammonia under milder conditions and through more environmentally friendly reaction paths are under development [117]. Reactors with built-in heat recovery systems are most commonly used for traditional ammonia synthesis [118], in which hot reaction products heat the reactants to the required temperature. The authors of the final paper in this theme, Tovazhnyanskyy et al. [52], reported on "Optimal Design of Welded Plate Heat Exchanger for Ammonia Synthesis Column: An Experimental Study with Mathematical Optimisation". They investigated heat transfer in a plate heat exchanger with a specially welded construction for use in ammonia synthesis. Plate heat exchangers (PHEs) are one of the high-efficiency types of compact heat exchangers with intensified heat transfer [119]. The main construction features and principles of 
operation and design for PHE have been well discussed in publications (see, e.g., Klemeš et al. [120]). The exchanger consists of round, corrugated plates on which criss-cross channels are arranged to allow cross-flow of streams. The authors carried out an experiment in a laboratory to determine the correlations between heat transfer and pressure drop in a single-pass heat exchanger at high temperature and high pressure. With this data, they were able to develop a mathematical model for the design and optimisation of individual parts of the heat exchanger with a multiple-pass flow regime. The model was validated on an industrial device that confirmed better heat transfer properties than the tubular heat exchanger commonly used in ammonia synthesis. They carried out an optimisation of the exchanger surface, in which the height of a rib and the number of passes were optimisation variables. The validity of this model was confirmed by the results of industrial tests performed with the prototype WPHE (Welded Plate Heat Exchanger) installed in the operating column of ammonia synthesis at temperatures of about $500{ }^{\circ} \mathrm{C}$ and pressure of about $32 \mathrm{MPa}$. The tests confirmed the reliability of WPHE and its efficiency compared to a tubular heat exchanger. It has a significantly lower weight and occupies a smaller volume, which increases the ammonia production capacity by up to $15 \%$. In addition, it has a higher heat transfer efficiency. The developed optimisation model allows for the optimal design of the exchanger plates and flow regime for specific operating conditions in an ammonia synthesis reactor.

\subsection{Integration of Renewables}

Many companies have sought replacements for fossil fuels from renewable sources in steam production to reduce $\mathrm{CO}_{2}$ emissions. It has been shown that in powdered milk production, almost $100 \%$ of energy could be supplied from renewables [121]. In the first article on this theme, entitled "Renewable Energy Integration for Steam Supply of Industrial Processes-A Food Processing Case Study", Hechelmann et al. [122] presented in detail several alternative technologies for steam generation using renewable sources, e.g., biogas and biomethane boilers, solid biomass boilers, fuel cells, micro gas turbine, solar panels, and heat pumps. The research was conducted for a plant producing wet animal food. Most of the steam was used for sterilisation. Batch production with large fluctuations in steam consumption is typical for such plants, so a dynamic simulation was performed for each technology using the MATLAB/Simulink program. Steam production with two natural gas boilers was considered as a reference case. Authors designed alternative renewable technologies; assessed the capital cost, energy cost, and $\mathrm{CO}_{2}$ emissions; and compared them to a reference case. The results of the analysis showed that the highest reduction of $\mathrm{CO}_{2}$ emissions (approx. $64 \%$ ) compared to the reference case would be achieved with a biomass boiler in combination with a biogas backup boiler to cover peak steam demands. Biomass has a low carbon footprint, and a low price; the increase in energy costs, in this case, was about $28 \%$. The smallest increase in energy costs $(6.6 \%)$ compared to the reference case was achieved with the use of solar collectors, but the reduction in emissions was very small. The use of fuel cells was associated with the largest increase in energy costs due to high investment and low thermal efficiency. The authors concluded that a biomass boiler, in combination with a steam storage tank, represents a reasonable compromise between the reduction of $\mathrm{CO}_{2}$ emissions and the increase in energy production cost.

The next article on this topic was a review paper, "Operational Management Implemented in Biofuel Upstream Supply Chain and Downstream International Trading: Current Issues in Southeast Asia", written by Hoo et al. [123]. The authors provided an overview of methods for strategic, tactical, and operational decision making in biofuel supply chain planning. On the upstream side, important decisions include biomass cultivation, availability, harvesting, the modes of transport, pretreatment and processing, product storage, distribution and inventories, and selection of locations. The methods considered in the literature use mathematical programming [124], heuristic approaches [125], and multi-objective optimisation [126] to optimise the biofuel supply chain. The downstream side includes, in particular, international trade in biomass and biofuels, in which there is considerable uncertainty, especially regarding prices and demand. Analyses of various scenarios, including pessimistic and 
optimistic situations, are common. It is important to include the impact of different policy instruments and measures on the international flow of biofuels, in addition to the barriers and drivers, in the optimisation models of regional and global biomass and biofuel supply chains. The goal is usually to maximise economic efficiency, but it is also necessary to optimise the overall footprint, which takes into account not only economic but also environmental and social impacts. The authors analysed the bioenergy situation in Malaysia, Indonesia, and Thailand in more detail. These countries have various sources of biomass (palm oil, cassava, sugar cane), and their governments employ several measures to encourage the increased use of biofuels in transportation, industry, electricity, and commercial uses. The authors concluded that sustainable biofuel supply chain planning requires a comprehensive approach and interdisciplinary research that enable appropriate policy decisions for sustainable resource use, reduced environmental impact, improved energy security, and economic growth.

In the article entitled "Determination of Various Parameters during Thermal and Biological Pretreatment of Waste Materials", the authors Hren et al. [127] examined how the pretreatment of waste materials affects their further conversion into useful products, such as biofuels and biofertilisers. With a suitable pretreatment, it is possible to increase the efficiency of waste recycling and improve the circular use of resources [128]. Two waste materials-sewage sludge and riverbank grass-and their mixtures were examined by applying thermal pretreatment at lower and higher temperatures, and biological pretreatment with the addition of cattle rumen enzyme at a lower temperature. Various parameters in the liquid phase (e.g., the content of nutrients $\mathrm{N}, \mathrm{P}$, and $\mathrm{K}$ ) before and after pretreatment were measured, in addition to the concentrations of $\mathrm{CH}_{4}, \mathrm{CO}_{2}$, and $\mathrm{H}_{2} \mathrm{~S}$ in the gas phase after pretreatment. The results of the experiments showed that thermal and biological pretreatment were most favourable at a lower temperature of $38.6^{\circ} \mathrm{C}$. The potassium and phosphorus concentrations increased in all substrates after pretreatment. The pretreatment of the grass and sludge mixture showed the highest concentrations of potassium compounds. The highest concentration of phosphorus was found in the pre-treated sludge. The total nitrogen content also increased in most cases during pretreatment, with the highest total nitrogen content found in the samples of sludge and its mixtures with grass. Analyses of the obtained gas phase show that the biological pretreatment of the sludge was most favourable at a temperature of $38.6^{\circ} \mathrm{C}$ because it results in the highest concentration of methane and the lowest concentration of $\mathrm{H}_{2} \mathrm{~S}$. The study suggested that the choice of the pretreatment process for waste material depends on the intended further use because the pretreatment influences the quality of the product made from waste material.

In the final paper on this topic, "Biowaste Treatment and Waste-To-Energy-Environmental Benefits", the authors Pavlas et al. [129] compared the environmental impacts of three well-developed biowaste processing technologies-composting [130], fermentation [131], and incineration of biowaste combined with residual municipal solid wastes [132]. Global Warming Potential (GWP) was used as a criterion for assessing the environmental impact [133]. The results showed that all of the studied technologies reduced greenhouse gas emissions, which means that the overall change in GWP for each technology was negative. The smallest reduction in GWP was shown for composting technology, which was the least costly and investment intensive. By fermenting biowaste, an almost four-fold reduction in greenhouse gas emissions was achieved compared to composting. The result of the incineration of bio-waste as a component of the residual municipal waste depends on the ratio of heat and electricity generated in the cogeneration unit because heat generation entails a greater reduction in GWP than electricity generation. If the incineration plant mainly produces heat for district heating, the reduction in GWP would be greater than for fermentation. If the primary production were electricity, the reduction in GWP would be smaller than for fermentation. The authors concluded that if heat utilisation is ensured, it is best to incinerate biowaste as a part of the residual municipal solid waste. Otherwise, from a greenhouse gas emissions perspective, it is better to collect biowaste separately and process it by fermentation. 


\subsection{Roles in Economic and Environmental Sustainability}

In energy-intensive plants that run on fossil fuels, it is essential to reduce greenhouse gas emissions. This can be achieved by introducing technologies for capture, utilisation, and storage of $\mathrm{CO}_{2}$ for such plants. In the first article on this topic, entitled "Techno-Economic and Environmental Evaluations of Decarbonized Fossil-Intensive Industrial Processes by Reactive Absorption and Adsorption $\mathrm{CO}_{2}$ Capture Systems", the authors Cormos et al. [134] analysed two technologies. The first was a well-known reactive gas-liquid absorption, where $\mathrm{CO}_{2}$ is absorbed in a solvent such as Methyl-DiEthanol-Amine (MDEA) [135]. Another technology was a newer reactive gas-solid adsorption system, in which $\mathrm{CO}_{2}$ is adsorbed onto solid calcium oxide, followed by thermal decomposition of the resulting calcium carbonate [136]. The authors conducted an analysis of techno-economic and environmental indicators for the integration of decarbonisation technologies into various processes, such as coal-based power generation, and steel and cement production. They compared several indicators, e.g., specific capital investment; production costs of electricity, steel, or cement; plant emissions; power consumption; power output; and avoided $\mathrm{CO}_{2}$ cost. The results showed that by integrating so-called decarbonisation technologies (more correctly decarbonisation emissions technologies), $\mathrm{CO}_{2}$ emissions were reduced by up to $90 \%$ compared to conventional plants without decarbonisation. However, the investment was higher, the efficiency lower, and the cost of produced electricity, steel, or cement higher. According to economic indicators, the use of pre-combustion capture technology is more favourable than post-combustion capture. Life Cycle Analysis showed that decarbonisation reduces the value of the Global Warming Potential, while other environmental indicators can increase, e.g., acidification, eutrophication, and toxicity. In the industrial processes studied in this paper, the technology of capturing $\mathrm{CO}_{2}$ by adsorption on solid calcium sorbent proved to be technologically and economically more favourable than the gas-liquid carbon capture system.

In the next article, Castor et al. [137] conducted "A Comparative Techno-Economic Analysis of Different Desalination Technologies in Off-Grid Islands". The authors compared the technical and economic properties of four desalination technologies to produce drinking water from seawater. These are multi-effect distillation, multi-stage flash, mechanical vapour compression, and reverse osmosis. These processes need a reliable energy source, and it is appropriate to integrate them with the energy production system, particularly on islands that are not connected to the power grid. The use of diesel generators is widespread on islands, but the use of renewable sources for water desalination, such as a combination of solar photovoltaic and reverse osmosis, is encouraged [138]. The authors used a system that combines a renewable source (photovoltaic) and a fossil source (diesel) while using a battery-based energy storage system. Using computer programs, the authors of this SI paper optimised the integrated energy-water system for a period of one year, taking into account hourly fluctuations in water and energy consumption. The cost of power, the cost of water, and the net present value of the costs of the various desalination technologies were calculated. The uncertainty in energy and water consumption was taken into account with a stochastic Monte Carlo simulation. The results show that diesel-based power production would dominate on smaller islands because of lower capital cost. At low fuel prices, distillation and flash desalination technologies would be suitable. If the fuel price is high, and a renewable source is preferred, the use of reverse osmosis could be preferred. This is especially true for large islands, where energy and water requirements are higher and high investment costs are offset by lower fuel consumption in reverse osmosis. Forecasts for $30 \mathrm{y}$ ahead indicate that the cost of water produced by reverse osmosis would be the lowest of all of the technologies studied, while energy costs are expected to remain comparable for all technologies.

Aluminium production is an important energy consumer and emitter of $\mathrm{CO}_{2}$ emissions, although the energy efficiency of this process has improved significantly [139]. Gomilšek et al. [140], in their article entitled "Carbon Emissions Constrained Energy Planning for Aluminum Products", conducted planning and optimisation for various sources of electricity used in the production of aluminium products, such as slugs and evaporator panels. Fossil fuel, renewable, and nuclear energy sources were considered in their study. Electricity mixes should be derived from different sources that do not exceed 
the $\mathrm{CO}_{2}$ emission values required by the legal framework. The first technique for $\mathrm{CO}_{2}$ Constrained Energy Planning (CCEP) is the insight-based graphical targeting approach referred to as CEPA (Carbon Emission Pinch Analysis) and developed in 2007 by Tan and Foo [141]. CEPA uses a graphical approach based on the principles of traditional PA [142]. The numerical targeting approach with the cascade analysis methodology was originally developed for resource conservation networks [143] and had its roots in the Problem Table Algorithm, and the Heat Cascade developed for Maximum Heat Recovery networks [144]. The numerical targeting approach was further extended to determine the amount of low-carbon-emissions energy required to achieve the specified emission limits. In the case of the production of specific aluminium products, the authors found that about $20 \%$ of the energy should be replaced by sources with zero or low $\mathrm{CO}_{2}$ emissions to achieve the prescribed target emission. Optimal source mixes for power generation that would ensure emission target values at minimum cost were identified using an optimisation approach. In the studies of different scenarios, fossil fuel sources and nuclear energy were selected. The renewable sources were not beneficial due to the still higher price of renewable energy. The cost of power generated from an optimal mix of resources would be $26 \%$ higher than for the current power mix. However, the prescribed $\mathrm{CO}_{2}$ emission targets would be met. Finally, the authors summarised the advantages and disadvantages of the approaches used and recommended the development of combined methods that exploit the advantages of each approach.

Yang et al. [145], the authors of the article entitled "A Method for Analysing Energy-Related Carbon Emissions and the Structural Changes: A Case Study of China from 2005 to 2015", used Sankey diagrams to show the structure of energy consumption and carbon emissions resulting from the consumption of fossil fuels in China. Sankey diagrams were used to analyse China's energy consumption in 2005 [146]. However, calculating the components of the TRO indicator as proposed by the authors allowed trends to be identified, such as changes in total carbon emissions for individual sectors $(\mathrm{T})$, relative growth in carbon emissions $(\mathrm{R})$, and changes in the ratio of carbon emissions from a particular sector to total emissions $(\mathrm{O})$. The visualisation of energy consumption and the resulting carbon emissions shows that coal is the predominant energy source and accounts for the largest share of emissions. Calculations of the individual components of the TRO index show that the share of coal in China's energy structure has decreased and natural gas has become an important energy source. The use of renewable resources, particularly wind energy, is developing. This paper concluded that the boom in the industry, the construction of infrastructure, and the rise in living standards are slowing the decline in coal consumption and the decarbonisation of the country. The methodology developed by the authors analyses the responsibility of the individual sectors for carbon emissions by visualisation and evaluates changes and trends using the TRO indicator. Thus, decision-makers can design more effective measures and solutions to reduce emissions.

Acrylic acid is an important chemical intermediate, used in particular by the polymer and textile industries to produce various end products. Premlall and Lokhat [147] report on simulation and design of acrylic acid production with a focus on its reactor system in an article entitled "Reducing Energy Requirements in the Production of Acrylic Acid: Simulation and Design of a Multitubular Reactor Train". The main objectives were more detailed design and optimisation of the reactor train and reduction of energy consumption. Two reaction steps were considered: the oxidation of propylene to acrolein and the oxidation of acrolein to acrylic acid. A plug-flow reactor model was used in Aspen Plus to simulate multitubular reactors with appropriate reaction kinetics for propylene oxidation [148] and for acrolein oxidation [149]. Side reactions produce $\mathrm{CO}_{2}$ and acetic acid, and it is important to select a catalyst with high selectivity. Bismuth molybdate and vanadium molybdate proved to be the most efficient catalysts for this application [150]. Authors of this SI paper determined the operating and design parameters of the reactor system, such as the number of tubes, the length of the reactor, the flow and temperature of the heat transfer fluid, the pressure drop, and the heat transfer area. To reduce energy consumption, the authors introduced an inert pre-heating zone into the first reactor. The heating medium used is molten salt, which absorbs the heat of the exothermic reaction and cools down again when the feed stream is preheated. Cold air is introduced into the outlet stream of the first 
reactor, which lowers the inlet temperature in the second reactor and increases the heat absorption capacity in this reactor. The authors concluded that it is possible to reduce energy consumption by about $7 \mathrm{MW}$ with the measures and optimisations they proposed.

A new idea based on the exergy concept was developed in the article "Thermodynamics-Based Process Sustainability Evaluation" by Varbanov et al. [151], who proposed the concepts of Exergy Profit and Footprint. All industrial and other human activities involve non-spontaneous processes and exergy is necessary to drive them. The authors developed the framework based on the concepts of exergy assets and liabilities for driving the processes. The formulated Exergy Profit criterion was demonstrated as an appropriate quantitative indicator of the sustainability contribution of the assessed processes. The concept of exergy is not as widespread as deserved because it is more abstract and often more difficult to understand, even for engineers, although it can be efficiently combined with energy and economic methods to comprehensively evaluate process systems [152]. The difficulty in its application can be seen from [153], who used exergy in their model but with a focus on the techno-economic optimisation of embedded multiple criteria, including environmental. Exergy assets are associated with the ability of process streams to extract useful work and drive the processes, including energy generation. Exergy liabilities represent the demands and deficits of exergy that have to be supplied to the processes. Exergy Profit and Footprint are calculated by balancing the assets and liabilities. The surplus of the assets over the liabilities results in the Exergy Profit whereas, in the case of deficit, an Exergy Footprint results. The sustainability contribution is higher for a higher value of the Exergy Profit. The concepts were illustrated with two examples from different problem domains. These were acetic acid waste recovery and reuse, in addition to the evaluation of municipal solid waste treatment options. This clearly demonstrated the applicability of the method to a wide range of systems.

\section{Suggestions for Research Focus and Development}

\subsection{Social Impact of Novel and Fast-Developing Methodologies}

Although sustainability is a critical element of advanced system design, the consideration of social factors remains limited compared to economic and environmental factors. Design with optimised economic and environmental performance would be too idealised to be fully accomplished without regard for social impacts that could overturn the situation. The importance of social dimensions and socio-technical aspects for the broader achievement of climate and energy targets at the local level were also discussed by Balest et al. [154]. Garcia-Casals et al. [155] stated that energy-economy transitions do not occur in isolation; they are embedded in the wider economy, which, in turn, is embedded in social and environmental systems. The overall system is complex and involves many sources of feedback between the subsystems leading to the final outcome. In addition to advanced technological solutions, future research should concentrate on social aspects, as a fuller understanding could enhance the effectiveness of system design.

\subsection{Energy Storage}

A crucial issue for both the deeper penetration of renewables with fluctuating performance, such as PV and wind and resolving peak and off-peak demands, is energy storage. Recently numerous interesting ideas have been published. Researchers from the Massachusetts Institute of Technology presented a noteworthy study [156] that analysed economic and environmental variability of the reuse of e-car batteries as stationary batteries for power storage. Similar contributions to circular economies should be the subject of future design development and implementation. The rapid development of advanced batteries is also taking place [157], for example, the development of nanographene batteries. Improving and reducing the cost of batteries represents a major research challenge that has attracted significant investment. 


\subsection{Implementation of IoT and Advanced Technologies}

IoT and other advanced technologies have made numerous important contributions. As an example, in addition to wasting a source of energy, leaked natural gas-mostly $\mathrm{CH}_{4}$-is a powerful GHG and a significant contributor to climate change [158]. A number of options have been proposed by leading oil companies [159] as next-generation detection devices, deployed from space orbit, from traditional high-altitude planes, and, most recently, from low-cost drones operating close to the ground; these latter devices are able to perform for long periods in self-managed automatic mode. Artificial intelligence, connected sensors, and data analytics will play an increasingly significant role in energy system design [160], renewable energy integration [161], predictive maintenance [162], and policy formulation. These approaches are currently being implemented in renewable energy technology companies [160].

\subsection{Non-Traditional Engineering Solutions}

As an example of non-tradition engineering solutions, used landfills have emerged as promising battery storage sites to back up renewable energy. Similar to solar panels, batteries may present a new revenue stream for closed landfills. This has been reported by Bandyk [163], with projects underway at several sites in the USA.

\section{Conclusions}

This review targeted novel developments in a rapidly developing field and was helpfully supported by a special topical issue presented in 2019 at the PRES 19 conference (Process Integration, Modelling and Optimisation for Energy Saving and Pollution Reduction), from which we selected 20 important papers. This conference was held at a venue on the Greek Island of Crete, benefiting from a clean island environment and serving as an intensive cross-fertilisation meeting of leading scientists from more than 50 countries. As an important extension to reviewing the selected Special Issue papers, this review article also provided a wider overview of a number of the most recent developments in heat integration and heat transfer; integrated and newly developed heat exchangers; integration of renewables; and roles in economic and environmental sustainability. Topics relating to emerging tools for the design of energy systems to increase economic and environmental sustainability were considered in the selection of the contributions. A wide variety of system design tools have been proposed and targeted for different energy-related issues. This review suggested that the achievement of a sustainable energy system design relies on social aspects receiving greater research attention, thus placing them on a level equal to that of economic and environmental concerns. The consideration of social impacts, including behaviour analysis, could further enhance the practicality of the tools for system design.

Author Contributions: Conceptualisation, Y.V.F. and J.J.K.; methodology, J.J.K. and Y.V.F.; formal analysis, Z.N.P., Y.V.F., J.J.K.; resources, Y.V.F., J.J.K., Z.N.P.; writing—original draft preparation, Y.V.F., Z.N.P., J.J.K.; writing—review and editing, Y.V.F., J.J.K., Z.N.P.; visualisation, Y.V.F., J.J.K.; supervision, project administration, funding acquisition J.J.K. All authors have read and agreed to the published version of the manuscript.

Funding: This research was funded by the EC supported project Sustainable Process Integration Laboratory - SPIL, grant number CZ.02.1.01/0.0/0.0/15_003/0000456 by Czech Republic Operational Programme Research, Development, and Education, Priority 1: Strengthening capacity for quality research under the collaboration agreement with the University of Maribor, Slovenia.

Conflicts of Interest: The authors declare no conflict of interest.

\section{References}

1. Hong, J.H.; Kim, J.; Son, W.; Shin, H.; Kim, N.; Lee, W.K.; Kim, J. Long-term energy strategy scenarios for South Korea: Transition to a sustainable energy system. Energy Policy 2019, 127, 425-437. [CrossRef]

2. Qin, J.; Liu, Y.; Grosvenor, R.; Lacan, F.; Jiang, Z. Deep learning-driven particle swarm optimisation for additive manufacturing energy optimisation. J. Clean. Prod. 2020, 245, 118702. [CrossRef] 
3. Liu, S.; Yuan, J.; Deng, W.; Luo, M.; Xie, Y.; Liang, Q.; Zou, Y.; He, Z.; Wu, H.; Cao, Y. High-efficiency organic solar cells with low non-radiative recombination loss and low energetic disorder. Nat. Photonics 2020, 14, 300-305. [CrossRef]

4. Ochoa, G.V.; Rojas, J.P.; Forero, J.D. Advance Exergo-Economic Analysis of a Waste Heat Recovery System Using ORC for a Bottoming Natural Gas Engine. Energies 2020, 13, 267. [CrossRef]

5. Marquant, J.F.; Mavromatidis, G.; Evins, R.; Carmeliet, J. Comparing different temporal dimension representations in distributed energy system design models. Energy Proc. 2017, 122, 907-912. [CrossRef]

6. Weinand, J.M.; McKenna, R.; Mainzer, K. Spatial high-resolution socio-energetic data for municipal energy system analyses. Sci. Data 2019, 6, 1-6. [CrossRef]

7. IEA. Renewables. 2020. Available online: www.iea.org/fuels-and-technologies/renewables (accessed on 4 June 2020).

8. Larsen, M.A.D.; Drews, M. Water use in electricity generation for water-energy nexus analyses: The European case. Sci. Total Environ. 2019, 651, 2044-2058. [CrossRef]

9. UCSUSA. Benefits of Renewable Energy Use. 2017. Available online: www.ucsusa.org/resources/benefitsrenewable-energy-use (accessed on 2 June 2020).

10. Fan, Y.V.; Klemeš, J.J.; Ko, C.H. Bioenergy carbon emissions footprint considering the biogenic carbon and secondary effects. Int. J. Energy Res. 2020. [CrossRef]

11. Schmidt, O.; Melchior, S.; Hawkes, A.; Staffell, I. Projecting the future levelized cost of electricity storage technologies. Joule 2019, 3, 81-100. [CrossRef]

12. Lazard. Levelized Cost of Energy and Levelized Cost Of Storage 2019. 2019. Available online: www.lazard. com/perspective/lcoe2019 (accessed on 1 June 2020).

13. Perera, A.T.D.; Nik, V.M.; Wickramasinghe, P.U.; Scartezzini, J.L. Redefining energy system flexibility for distributed energy system design. Appl. Energy 2019, 253, 113572. [CrossRef]

14. WNA (World Nuclear Association). Comparison of Lifecycle Greenhouse Gas Emissions of Various Electricity Generation Sources. 2011. Available online: www.world-nuclear.org/uploadedFiles/org/WNA/Publications/ Working_Group_Reports/comparison_of_lifecycle.pdf (accessed on 4 June 2020).

15. Jin, Y.; Behrens, P.; Tukker, A.; Scherer, L. Water use of electricity technologies: A global meta-analysis. Renew. Sustain. Energy Rev. 2019, 115, 109391. [CrossRef]

16. Mekonnen, M.M.; Gerbens-Leenes, P.W.; Hoekstra, A.Y. The consumptive water footprint of electricity and heat: A global assessment. Environ. Sci. Water Res. Technol. 2015, 1, 285-297. [CrossRef]

17. Asdrubali, F.; Baldinelli, G.; D'Alessandro, F.; Scrucca, F. Life cycle assessment of electricity production from renewable energies: Review and results harmonisation. Renew. Sustain. Energy Rev. 2015, 42, 1113-1122. [CrossRef]

18. Amponsah, N.Y.; Troldborg, M.; Kington, B.; Aalders, I.; Hough, R.L. Greenhouse gas emissions from renewable energy sources: A review of lifecycle considerations. Renew. Sustain. Energy Rev. 2014, 39, 461-475. [CrossRef]

19. EEA. Renewable Energy Impacts Dashboard. 2019. Available online: www.eea.europa.eu/themes/energy/ renewable-energy/renewables-crucial-for-eu-decarbonisation (accessed on 4 June 2020).

20. Lazard. Lazard's Levelised Cost of Energy Analysis-Version 11.0. 2019. Available online: www.lazard.com/ media/450337/lazard-levelized-cost-of-energy-version-110.pdf (accessed on 2 June 2020).

21. Lazard. Lazard's Levelised Cost of Energy Analysis-Version 12.0. 2019. Available online: www.lazard.com/ media/450784/lazards-levelized-cost-of-energy-version-120-vfinal.pdf (accessed on 2 June 2020).

22. Taylor, M. Cheaper than coal: IRENA's Comprehensive Report on Cost Declines all Renewables Categories. 2019. Available online: energypost.eu/cheaper-than-coal-irenas-comprehensive-report-on-cost-declines-allrenewables-categories/ (accessed on 2 June 2020).

23. Fiksel, J. Designing resilient, sustainable systems. Environ. Sci. Technol. 2003, 37, 5330-5339. [CrossRef] [PubMed]

24. Kambhampati, U.S. The Whole Idea of Global Value Chains will be Reconsidered After Coronavirus. 2020. Available online: theconversation.com/the-whole-idea-of-global-value-chains-will-be-reconsidered-aftercoronavirus-137132 (accessed on 4 June 2020).

25. IEA. Clean Energy Progress after the Covid-19 Crisis will need Reliable Supplies of Critical Minerals. 2020. Available online: www.iea.org/articles/clean-energy-progress-after-the-covid-19-crisis-will-need-reliablesupplies-of-critical-minerals\#reference-4 (accessed on 4 June 2020). 
26. Statista. Major Countries in Worldwide Zinc Mine Production from 2010-2019. 2020. Available online: www.statista.com/statistics/264634/zinc-production-by-country/ (accessed on 4 June 2020).

27. Statista. Major Countries Silicon Production from 2014-2019. 2020. Available online: www.statista.com/ statistics/268108/world-silicon-production-by-country// (accessed on 4 June 2020).

28. IEA. Reductions of Electricity Demand after Implementing Lockdown Measures in Selected Countries, Weather Corrected, 0 to 68 Days. 2020. Available online: www.iea.org/data-and-statistics/charts/reductionsof-electricity-demand-after-implementing-lockdown-measures-in-selected-countries-weather-corrected0-to-68-days/ (accessed on 4 June 2020).

29. IEA. Energy Investment is Set to Fall by One Fifty in 2020 due to the Covid-19 Pandemic. 2020. Available online: www.iea.org/reports/world-energy-investment-2020/key-findings\#abstract (accessed on 4 June 2020).

30. Amelang, S. Negative Electricity Prices: Lockdown's Demand Slump Exposes Inflexibility of German Power. 2020. Available online: energypost.eu/negative-electricity-prices-lockdowns-demand-slump-exposesinflexibility-of-german-power/ (accessed on 4 June 2020).

31. Meinrenken, C.; Modi, V.; Mckeown, K.; Culligan, P. New data suggest COVID-19 is shifting the burden of energy cost to households. 2020. Available online: blogs.ei.columbia.edu/2020/04/21/covid-19-energy-costshouseholds// (accessed on 4 June 2020).

32. Amelang, S. Coronavirus Lockdown Pushes Up Heating Demand Across Europe-Report. 2020. Available online: www.cleanenergywire.org/news/coronavirus-lockdown-pushes-heating-demand-across-europereport/ (accessed on 4 June 2020).

33. Kortenhorst, J. Here's What we Know and Don't Know about the Energy Transition. 2020. Available online: www.weforum.org/agenda/2020/04/heres-what-the-pandemic-means-for-the-energy-transition// (accessed on 4 June 2020.).

34. WARTSILA. European Responses to Covid-19 Accelerate the Electricity System Transition by a Decade. 2020. Available online: news.cision.com/wartsila-corporation/r/european-responses-to-covid-19-accelerate-theelectricity-system-transition-by-a-decade--according-t,c3090780/ (accessed on 4 June 2020).

35. BBC. Coronavirus: Domestic Electricity use up During Day as Nation Works From Home. 2020. Available online: www.bbc.com/news/technology-52331534/ (accessed on 4 June 2020).

36. Korhonen, J.; Honkasalo, A.; Seppälä, J. Circular economy: The concept and its limitations. Ecol. Econ. 2018, 143, 37-46. [CrossRef]

37. Kirchherr, J.; Reike, D.; Hekkert, M. Conceptualising the circular economy: An analysis of 114 definitions. Resour. Conserv. Recycl. 2017, 127, 221-232. [CrossRef]

38. Mayer, A.; Haas, W.; Wiedenhofer, D.; Krausmann, F.; Nuss, P.; Blengini, G.A. Measuring Progress towards a Circular Economy: A Monitoring Framework for Economy-wide Material Loop Closing in the EU28. J. Ind. Ecol. 2019, 23, 62-76. [CrossRef]

39. Moraga, G.; Huysveld, S.; Mathieux, F.; Blengini, G.A.; Alaerts, L.; Van Acker, K.; de Meester, S.; Dewulf, J. Circular economy indicators: What do they measure? Resour. Conserv. Recycl. 2019, 146, 452-461. [CrossRef]

40. Loucks, D.P.; van Beek, E. Models for Identifying and Evaluating Alternatives. In Water Resource Systems Planning and Management; Springer: Cham, Switzerland, 2017; pp. 73-91.

41. LLNL (Lawrence Livermore National Laboratory). Energy Flow Chart. Available online: flowcharts.llnl.gov/ (accessed on 4 June 2020).

42. Papapetrou, M.; Kosmadakis, G.; Cipollina, A.; La Commare, U.; Micale, G. Industrial waste heat: Estimation of the technically available resource in the EU per industrial sector, temperature level and country. Appl. Therm. Eng. 2018, 138, 207-216. [CrossRef]

43. Bianchi, G.; Panayiotou, G.P.; Aresti, L.; Kalogirou, S.A.; Florides, G.A.; Tsamos, K.; Christodoulides, P. Estimating the waste heat recovery in the European Union Industry. Energy Ecol. Environ. 2019, 4, 211-221. [CrossRef]

44. Klemeš, J.J.; Varbanov, P.V.; Walmsley, T.G.; Jia, X.X. New directions in the implementation of Pinch Methodology (PM). Renew. Sustain. Energy Rev. 2018, 98, 439-468. [CrossRef]

45. Klemeš, J.J.; Varbanov, P.S. Process Intensification and Integration: An assessment. Clean Technol. Environ. Policy 2013, 15, 417-422. [CrossRef]

46. Klemeš, J.J. (Ed.) Assessing and Measuring Environmental Impact and Sustainability; Elsevier/Butterworth-Heinemann: Oxford, UK, 2015; 559p, ISBN 978-0-12-799968-5. 
47. Čuček, L.; Klemeš, J.J.; Kravanja, Z. A Review of Footprint Analysis Tools for Monitoring Impacts on Sustainability. J. Clean. Prod. 2012, 34, 9-20. [CrossRef]

48. Mann, M.E. Greenhouse Gas. 2019. Available online: www.britannica.com/science/greenhouse-gas\#ref280534 (accessed on 1 June 2020).

49. Klemeš, J.J.; Wang, Q.W.; Varbanov, P.S.; Zeng, M.; Chin, H.H.; Lal, N.S.; Li, N.Q.; Wang, B.; Wang, X.C.; Walmsley, T.G. Heat transfer enhancement, intensification and optimisation in heat exchanger network retrofit and operation. Renew. Sustain. Energy Rev. 2020, 120, 109644. [CrossRef]

50. Forsberg, C.H. Heat Transfer Principles and Applications; Academic Press/Elsevier: Cambridge, MA, USA, 2020. [CrossRef]

51. Luo, A.; Fang, H.; Xia, J.; Lin, B.; Yiang, Y. Mapping potentials of low-grade industrial waste heat in Northern China. Resour. Conserv. Recycl. 2017, 125, 335-348. [CrossRef]

52. Tovazhnyanskyy, L.; Klemeš, J.J.; Kapustenko, P.; Arsenyeva, O.; Perevertaylenk, O.; Arsenyev, P. Optimal Design of Welded Plate Heat Exchanger for Ammonia Synthesis Column: An Experimental Study with Mathematical Optimisation. Energies 2020, 13, 2847. [CrossRef]

53. Vergara-Dietrich, J.D.; Morato, M.M.; Mendes, P.R.; Cani, A.A.; Normey-Rico, J.E.; Bordons, C. Advanced chance-constrained predictive control for the efficient energy management of renewable power systems. J. Process Control 2019, 74, 120-132. [CrossRef]

54. Alavi, S.A.; Ahmadian, A.; Aliakbar-Golkar, M. Optimal probabilistic energy management in a typical micro-grid based-on robust optimisation and point estimate method. Energy Convers. Manag. 2015, 95, 314-325. [CrossRef]

55. Mehrjerdi, H.; Rakhshani, E. Correlation of multiple time-scale and uncertainty modelling for renewable energy-load profiles in wind powered system. J. Clean. Prod. 2019, 236, 117644. [CrossRef]

56. Talaat, M.; Farahat, M.A.; Elkholy, M.H. Renewable power integration: Experimental and simulation study to investigate the ability of integrating wave, solar and wind energies. Energy 2019, 170, 668-682. [CrossRef]

57. Baum, Z.; Palatnik, R.R.; Ayalon, O.; Elmakis, D.; Frant, S. Harnessing households to mitigate renewables intermittency in the smart grid. Renew. Energy 2019, 132, 1216-1229. [CrossRef]

58. Fiedler, T. Simulation of a power system with large renewable penetration. Renew. Energy 2019, 130, 319-328. [CrossRef]

59. Draycott, S.; Sellar, B.; Davey, T.; Noble, D.R.; Venugopal, V.; Ingram, D.M. Capture and simulation of the ocean environment for offshore renewable energy. Renew. Sustain. Energy Rev. 2019, 104, 15-29. [CrossRef]

60. Wagh, M.M.; Kulkarni, V.V. Modeling and optimisation of integration of Renewable Energy Resources (RER) for minimum energy cost, minimum $\mathrm{CO}_{2}$ Emissions and sustainable development, in recent years: A review. Mater. Today Proc. 2018, 5, 11-21. [CrossRef]

61. Al Nouss, A.; McKay, G.; Al-Ansari, T. Production of syngas via gasification using optimum blends of biomass. J. Clean. Prod. 2020, 242, 118499. [CrossRef]

62. Peng, Z.; Herfatmanesh, M.R.; Liu, Y. Cooled solar PV panels for output energy efficiency optimisation. Energy Convers. Manag. 2017, 150, 949-955. [CrossRef]

63. Bravo, R.; Ortiz, C.; Chacartegui, R.; Friedrich, D. Hybrid solar power plant with thermochemical energy storage: A multi-objective operational optimisation. Energy Convers. Manag. 2020, 205, 112421. [CrossRef]

64. Zheng, Y.; Jenkins, B.M.; Kornbluth, K.; Kendall, A.; Træholt, C. Optimisation of a biomass-integrated renewable energy microgrid with demand side management under uncertainty. Appl. Energy 2018, 230, 836-844. [CrossRef]

65. Nowdeh, S.A.; Davoudkhani, I.F.; Moghaddam, M.H.; Najmi, E.S.; Abdelaziz, A.Y.; Ahmadi, A.; Gandoman, F.H. Fuzzy multi-objective placement of renewable energy sources in distribution system with objective of loss reduction and reliability improvement using a novel hybrid method. Appl. Soft Comput. 2019, 77, 761-779. [CrossRef]

66. Jafari, A.; Khalili, T.; Ganjehlou, H.G.; Bidram, A. Optimal integration of renewable energy sources, diesel generators, and demand response program from pollution, financial, and reliability viewpoints: A multi-objective approach. J. Clean. Prod. 2020, 247, 119100. [CrossRef]

67. Rinaldi, A.; Soini, M.C.; Patel, M.K.; Parra, D. Optimised allocation of PV and storage capacity among different consumer types and urban settings: A prospective analysis for Switzerland. J. Clean. Prod. 2020, 259, 120762. [CrossRef] 
68. Santibañez-Aguilar, J.E.; Castellanos, S.; Flores-Tlacuahuac, A.; Shapiro, B.B.; Powell, D.M.; Buonassisi, T.; Kammen, D.M. Design of domestic photovoltaics manufacturing systems under global constraints and uncertainty. Renew. Energy 2020, 148, 1174-1189. [CrossRef]

69. Zakaria, A.; Ismail, F.B.; Lipu, M.H.; Hannan, M.A. Uncertainty models for stochastic optimisation in renewable energy applications. Renew. Energy 2020, 145, 1543-1571. [CrossRef]

70. Aviso, K.B.; Marfori, I.A.V.; Tan, R.R.; Ubando, A.T. Optimising abnormal operations of off-grid community utility systems with fuzzy P-graph. Energy 2020, 202, 117725. [CrossRef]

71. Cuesta, M.A.; Castillo-Calzadilla, T.; Borges, C.E. A critical analysis on hybrid renewable energy modeling tools: An emerging opportunity to include social indicators to optimise systems in small communities. Renew. Sustain. Energy Rev. 2020, 122, 109691. [CrossRef]

72. Akhtari, M.R.; Shayegh, I.; Karimi, N. Techno-economic assessment and optimisation of a hybrid renewable earth-air heat exchanger coupled with electric boiler, hydrogen, wind and PV configurations. Renew. Energy 2020, 148, 839-851. [CrossRef]

73. Armin Razmjoo, A.; Sumper, A.; Davarpanah, A. Energy sustainability analysis based on SDGs for developing countries. Energy Sources Part A Recovery Util. Environ. Eff. 2020, 42, 1041-1056. [CrossRef]

74. Baldasso, E.; Mondejar, M.E.; Larsen, U.; Haglind, F. Regression Models for the Evaluation of the Techno-Economic Potential of Organic Rankine Cycle-Based Waste Heat Recovery Systems on Board Ships Using Low Sulfur Fuels. Energies 2020, 13, 1378. [CrossRef]

75. Khoshnevisan, B.; Tabatabaei, M.; Tsapekos, P.; Rafiee, S.; Aghbashlo, M.; Lindeneg, S.; Angelidaki, I. Environmental life cycle assessment of different biorefinery platforms valorising municipal solid waste to bioenergy, microbial protein, lactic and succinic acid. Renew. Sustain. Energy Rev. 2020, 117, 109493. [CrossRef]

76. Ramírez-Islas, M.E.; Güereca, L.P.; Sosa-Rodriguez, F.S.; Cobos-Peralta, M.A. Environmental assessment of energy production from anaerobic digestion of pig manure at medium-scale using life cycle assessment. Waste Manag. 2020, 102, 85-96. [CrossRef] [PubMed]

77. Longo, S.; Beccali, M.; Cellura, M.; Guarino, F. Energy and environmental life-cycle impacts of solar-assisted systems: The application of the tool "ELISA". Renew. Energy 2020, 145, 29-40. [CrossRef]

78. Stamford, L. Life cycle sustainability assessment in the energy sector. In Biofuels for a More Sustainable Future; Elsevier: Amsterdam, The Netherlands; Oxford, UK; Cambridge, MA, USA, 2020; pp. 115-163.

79. Duan, C.; Chen, B. Driving factors of water-energy nexus in China. Appl. Energy 2020, 257, 113984. [CrossRef]

80. Fan, Y.V.; Tan, R.R.; Klemeš, J.J. A system analysis tool for sustainable biomass utilisation considering the Emissions-Cost Nexus. Energy Convers. Manag. 2020, 210, 112701. [CrossRef]

81. Razmjoo, A.A.; Sumper, A.; Davarpanah, A. Development of sustainable energy indexes by the utilisation of new indicators: A comparative study. Energy Rep. 2019, 5, 375-383. [CrossRef]

82. Liu, G. Development of a general sustainability indicator for renewable energy systems: A review. Renew. Sustain. Energy Rev. 2014, 31, 611-621. [CrossRef]

83. Jóźwiak, P.; Hercog, J.; Kiedrzyńska, A.; Badyda, K.; Olevano, D. Thermal Effects of Natural Gas and Syngas Co-Firing System on Heat Treatment Process in the Preheating Furnace. Energies 2020, 13, 1698. [CrossRef]

84. Echi, S.; Bouabidi, A.; Driss, Z.; Abid, M.S. CFD simulation and optimisation of industrial boiler. Energy 2019, 169, 105-114. [CrossRef]

85. Silva, J.; Teixeira, J.; Teixeira, S.; Preziati, S.; Cassiano, J. CFD Modeling of Combustion in Biomass Furnace. Energy Proc. 2017, 120, 665-672. [CrossRef]

86. You, S.; Ok, Y.S.; Tsang, D.C.W.; Kwon, E.; Wang, C.-H. Towards practical application of gasification: A critical review from syngas and biochar perspectives. Crit. Rev. Environ. Sci. Technol. 2018, 48, 1165-1213. [CrossRef]

87. Hancsók, J.; Kasza, T.; Visnyei, O. Isomerisation of n-C5/C6 Bioparaffins to Gasoline Components with High Octane Number. Energies 2020, 13, 1672. [CrossRef]

88. Wang, T.; Zhang, Q.; Ding, M.; Wang, C.; Li, Y.; Zhang, Q.; Ma, L. Bio-gasoline production by coupling of biomass catalytic pyrolysis and oligomerisation. Energy Proc. 2017, 105, 858-863. [CrossRef]

89. Sauciuc, A.; Abosteif, Z.; Weber, G.; Potetz, A.; Rauch, R.; Hofbauer, H.; Schaub, G.; Dumitrescu, L. Influence of operating conditions on the performance of biomass-based Fischer-Tropsch synthesis. Biomass Convers. Biorefin. 2012, 2, 253-263. [CrossRef] 
90. Kwon, E.E.; Kim, Y.T.; Kim, H.J.; Lin, K.Y.L.; Kim, K.H.; Lee, J.; Huber, G.W. Production of high-octane gasoline via hydrodeoxygenation of sorbitol over palladium-based bimetallic catalysts. J. Environ. Manag. 2018, 227, 329-334. [CrossRef]

91. Huber, G.W.; Chedda, J.N.; Barre, C.J.; Dumestic, J.A. Production of liquid alkanes by aqueous-phase processing of biomass-derived carbohydrates. Science 2005, 308, 1446-1450. [CrossRef] [PubMed]

92. Tian, X.; Yang, J.; Guo, Z.; Wang, Q.; Sunden, B. Numerical Study of Heat Transfer in Gravity-Driven Particle Flow around Tubes with Different Shapes. Energies 2020, 13, 1961. [CrossRef]

93. Bartsch, P.; Zunft, S. Granular flow around the horizontal tubes of a particle heat exchanger: DEM-simulation and experimental validation. Solar Energy 2019, 182, 48-56. [CrossRef]

94. Liu, J.; Yu, Q.; Peng, J.; Hu, X.; Duan, W. Thermal energy recovery from high-temperature blast furnace slag particles. Int. Commun. Heat Mass Transfer 2015, 69, 23-28. [CrossRef]

95. Létal, T.; Turek, V.; Babička Fialová, D.; Jegla, Z. Nonlinear Finite Element Analysis-Based Flow Distribution and Heat Transfer Model. Energies 2020, 13, 1664. [CrossRef]

96. Zhou, J.; Ding, M.; Bian, H.; Zhang, Y.; Sun, Z. Characteristics of flow distribution in central-type compact parallel-flow heat exchangers with modified inlet and header. Appl. Therm. Eng. 2020, 166, 114636. [CrossRef]

97. Łopata, S.; Ocłon, P.; Stelmach, T. Investigation of flow non-uniformities in the cross-flow heat exchanger with elliptical tubes. E3S Web Conf. 2019, 108, 01009. [CrossRef]

98. Karvounis, P.; Koubogiannis, D.; Hontzopoulos, E.; Hatziapostolou, A. Numerical and experimental study of flow characteristics in solar collector manifolds. Energies 2019, 12, 1431. [CrossRef]

99. Pismennyi, E.; Polupan, G.; Carvajal-Mariscal, I.; Sanchez-Silva, F.; Pioro, I. Examples of calculations. In Handbook for Transversely Finned Tube Heat Exchanger Design; Academic Press: Cambridge, MA, USA, 2016; Chapter 7; pp. 83-106.

100. ANSYS, Inc. ANSYS Fluent User's Guide, Version 2019 R3; ANSYS, Inc.: Canonsburgh, PA, USA, 2019.

101. Tang, W.; Kukulka, D.; Li, W.; Smith, R. Comparison of the Evaporation and Condensation Heat Transfer Coefficients on the External Surface of Tubes in the Annulus of a Tube-in-Tube Heat Exchanger. Energies 2020, 13, 952. [CrossRef]

102. Shafaee, M.; Mashouf, H.; Sarmadian, A.; Mohseni, S.G. Evaporation heat transfer and pressure drop characteristics of R-600a in horizontal smooth and helically dimpled tubes. Appl. Eng. 2016, 107, 28-36. [CrossRef]

103. Li, W.; Chen, X.; Chen, J.-X.; Sun, Z.-C.; Simon, T.W. Shell-Side Flow Condensation of R410A on Horizontal Tubes at Low-Mass Fluxes. J. Heat Transf. 2016, 139, 011501. [CrossRef]

104. Gai, L.; Varbanov, P.; Walmsley, T.; Klemeš, J. Critical Analysis of Process Integration Options for Joule-Cycle and Conventional Heat Pumps. Energies 2020, 13, 635. [CrossRef]

105. Radermacher, R.; Hwang, Y. Vapor Compression Heat Pumps with Refrigerant Mixes; Taylor \& Francis: Boca Raton, FL, USA, 2005.

106. Lorentzen, G. Trans-Critical Vapour Compression Cycle. Device. Patent Application No. WO1990007683A1, 12 July 1990.

107. Fu, C.; Gundersen, T. A Novel Sensible Heat Pump Scheme for Industrial Heat Recovery. Ind. Eng. Chem. Res. 2016, 55, 967-977. [CrossRef]

108. Wang, B.; Klemeš, J.; Varbanov, P.; Zeng, M. An Extended Grid Diagram for Heat Exchanger Network Retrofit Considering Heat Exchanger Types. Energies 2020, 13, 2656. [CrossRef]

109. Yong, J.Y.; Varbanov, P.S.; Klemeš, J.J. Heat exchanger network retrofit supported by extended Grid Diagram and heat path development. Appl. Therm. Eng. 2015, 89, 1033-1045. [CrossRef]

110. Soršak, A.; Kravanja, Z. Simultaneous MINLP synthesis of heat exchanger networks comprising different exchanger types. Comput. Chem. Eng. 2002, 26, 599-615. [CrossRef]

111. Yong, J.Y.; Varbanov, P.S.; Klemeš, J.J. Shifted retrofit thermodynamic diagram: A modified tool for retrofitting heat exchanger networks. Chem. Eng. Trans. 2014, 39, 97-102.

112. Langner, C.; Svensson, E.; Harvey, S.A. Framework for Flexible and Cost-Efficient Retrofit Measures of Heat Exchanger Networks. Energies 2020, 13, 1472. [CrossRef]

113. Short, M.; Isafiade, A.J.; Fraser, D.M.; Kravanja, Z. Two-step hybrid approach for the synthesis of multi-period heat exchanger networks with detailed exchanger design. Appl. Therm. Eng. 2016, 105, 807-821. [CrossRef]

114. Pintarič, Z.N.; Kravanja, Z.A. Methodology for the synthesis of heat exchanger networks having large numbers of uncertain parameters. Energy 2015, 92, 373-382. [CrossRef] 
115. Sheng, Y.; Liu, L.; Zhuang, Y.; Zhang, L.; Du, J. Simultaneous Synthesis of Heat Exchanger Networks Considering Steam Supply and Various Steam Heater Locations. Energies 2020, 13, 1467. [CrossRef]

116. Elsido, C.; Martelli, E.; Grossmann, I.E. A Bilevel Decomposition Method for the Simultaneous Synthesis of Utility Systems, Rankine Cycles and Heat Exchanger Networks. Comp. Aided Process Eng. 2018, 43, 373-378.

117. Wang, Q.; Guo, J.; Chen, P. Recent progress towards mild-condition ammonia synthesis. J. Energy Chem. 2019, 36, 25-36. [CrossRef]

118. Khademi, M.H.; Sabbaghi, R.S. Comparison between three types of ammonia synthesis reactor configurations in terms of cooling methods. Chem. Eng. Res. Des. 2017, 128, 306-317. [CrossRef]

119. Arsenyev, P.Y.; Tovazhnyansky, L.; Klemeš, J.J.; Arsenyeva, O.P.; Perevertaylenko, O.Y.; Kapustenko, P.O. The Optimal Design of Welded Plate Heat Exchanger with Intensified Heat Transfer for Ammonia Synthesis Column. Chem. Eng. Trans. 2019, 76, 61-66.

120. Klemeš, J.J.; Arsenyeva, O.; Kapustenko, P.; Tovazhnyanskyy, L. Compact Heat Exchangers for Energy Transfer Intensification; CRC Press/Taylor \& Francis Company: New York, NY, USA, 2015; Volume 372, pp. 54-65, ISBN-13: 978-1482232592.

121. Walmsley, M.R.; Walmsley, T.G.; Atkins, M.J.; Neale, J.R. Sustainable Milk Powder Production using Enhanced Process Integration and 100\% Renewable Energy. Chem. Eng. Trans. 2016, 2016, 559-564.

122. Hechelmann, R.; Seevers, J.; Otte, A.; Sponer, J.; Stark, M. Renewable Energy Integration for Steam Supply of Industrial Processes-A Food Processing Case Study. Energies 2020, 13, 253. [CrossRef]

123. Hoo, P.Y.; Phun Chien, C.; Fan, Y.V. Operational Management Implemented in Biofuel Upstream Supply Chain and Downstream International Trading: Current Issues in Southeast Asia. Energies 2020, 13, 1799.

124. Čuček, L.; Martín, M.; Grossmann, I.E.; Kravanja, Z. Multi-Period Synthesis of Optimally Integrated Biomass and Bioenergy Supply Network. Comput. Chem. Eng. 2014, 66, 57-70. [CrossRef]

125. Asadi, E.; Habibi, F.; Nickel, S.; Sahebi, H.A. Bi-Objective Stochastic Location-Inventory-Routing Model for Microalgae-Based Biofuel Supply Chain. Appl. Energy 2018, 228, 2235-2261. [CrossRef]

126. How, B.S.; Lam, H.L. Integrated Palm Biomass Supply Chain toward Sustainable Management. Chem. Prod. Process Model. 2017, 12, 1-19. [CrossRef]

127. Hren, R.; Petrovič, A.; Čuček, L.; Simonič, M. Determination of Various Parameters during Thermal and Biological Pretreatment of Waste Materials. Energies 2020, 13, 2262. [CrossRef]

128. Seidl, P.R.; Goulart, A.K. Pretreatment processes for lignocellulosic biomass conversion to biofuels and bioproducts. Curr. Opin. Green Sustain. Chem. 2016, 2, 48-53. [CrossRef]

129. Pavlas, M.; Dvořáček, J.; Pitschke, T.; Peche, R. Biowaste Treatment and Waste-To-Energy—Environmental Benefits. Energies 2020, 13, 1994. [CrossRef]

130. Reyes-Torres, M.; Oviedo-Ocaña, E.R.; Dominguez, I.; Komilis, D.; Sánchez, A.A. Systematic review on the composting of green waste: Feedstock quality and optimisation strategies. Waste Manag. 2018, 77, 486-499. [CrossRef]

131. Fan, Y.V.; Klemeš, J.J.; Lee, C.T.; Perry, S. Anaerobic digestion of municipal solid waste: Energy and carbon emission footprint. J. Environ. Manag. 2018, 223, 888-897. [CrossRef]

132. Ferdan, T.; Pavlas, M.; Nevrlý, V.; Šomplák, R. Greenhouse Gas Emissions from Thermal Treatment of Non-Recyclable Municipal Waste. Front. Chem. Sci. Eng. 2018, 12, 815-831. [CrossRef]

133. Jensen, M.B.; Møller, J.; Scheutz, C. Comparison of the organic waste management systems in the Danish-German border region using life cycle assessment (LCA). Waste Manag. 2016, 49, 491-504. [CrossRef] [PubMed]

134. Cormos, A.; Dragan, S.; Petrescu, L.; Sandu, V.; Cormos, C. Techno-Economic and Environmental Evaluations of Decarbonized Fossil-Intensive Industrial Processes by Reactive Absorption $\mathrm{CO}_{2}$ Capture Systems. Energies 2020, 13, 1268. [CrossRef]

135. Fang, M.; Yi, N.; Di, W.; Wang, T.; Wang, Q. Emission and control of flue gas pollutants in $\mathrm{CO}_{2}$ chemical absorption system-A review. Int. J. Greenh. Gas Control 2020, 93, 102904. [CrossRef]

136. Fan, L.S. Chemical Looping Systems for Fossil Energy Conversions; Wiley-AIChE: Hoboken, NJ, USA, 2010.

137. Castro, M.; Alcanzare, M.; Esparcia, E.; Ocon, J.A. Comparative Techno-Economic Analysis of Different Desalination Technologies in Off-Grid Islands. Energies 2020, 13, 2261. [CrossRef]

138. Tafech, A.; Milani, D.; Abbas, A. Water storage instead of energy storage for desalination powered by renewable energy_King Island case study. Energies 2016, 9, 839. [CrossRef] 
139. Haraldsson, J.; Johansson, M.T. Energy efficiency in the supply chains of the aluminium industry: The cases of five products made in Sweden. Energies 2019, 12, 245. [CrossRef]

140. Gomilšek, R.; Čuček, L.; Homšak, M.; Tan, R.; Kravanja, Z. Carbon Emissions Constrained Energy Planning for Aluminum Products. Energies 2020, 13, 2753. [CrossRef]

141. Tan, R.R.; Foo, D.C. Pinch analysis approach to carbon-constrained energy sector planning. Energy 2007, 562, 1422-1429. [CrossRef]

142. Foo, D.C.; Tan, R.R.; Ng, D.K. Carbon and footprint-constrained energy planning using cascade analysis technique. Energy 2008, 33, 1480-1488. [CrossRef]

143. Manan, Z.A.; Tan, Y.L.; Foo, D.C.Y. Targeting the minimum water flow rate using water cascade analysis technique. AIChE J. 2004, 50, 3169-3183. [CrossRef]

144. Klemeš, J.J.; Varbanov, P.S.; Kravanja, Z. Recent Developments in Process Integration. Chem. Eng. Res. Des. 2013, 91, 2037-2053. [CrossRef]

145. Yang, H.; Ma, L.; Li, Z.A. Method for Analysing Energy-Related Carbon Emissions and the Structural Changes: A Case Study of China from 2005 to 2015. Energies 2020, 13, 2076. [CrossRef]

146. Ma, L.; Allwood, J.M.; Cullen, J.M.; Li, Z. The use of energy in China: Tracing the flow of energy from a primary source to demand drivers. Energy 2012, 40, 174-188. [CrossRef]

147. Premlall, K.; Lokhat, D. Reducing Energy Requirements in the Production of Acrylic Acid: Simulation and Design of a Multitubular Reactor Train. Energies 2020, 13, 1971. [CrossRef]

148. Redlingshofer, H.; Fischer, A.; Weckbecker, K.H.; Emig, G. Kinetic modelling of the heterogeneously catalysed oxidation of propene to acrolein in a catalytic wall reactor. Ind. Eng. Chem. Res. 2003, 42, 5482-5488. [CrossRef]

149. Estenfelder, M.; Lintz, H.G. Simultaneous determination of reaction kinetics and oxygen activity in single-phase oxidic catalysts and their mixture during partial oxidations. J. Catal. 2002, 209, 177-185. [CrossRef]

150. Snyder, T.P.; Hill, C.G. The mechanism for the partial oxidation of propylene over bismuth molybdate catalysts. Catal. Rev. 1989, 31, 43-95. [CrossRef]

151. Varbanov, P.S.; Chin, H.H.; Popescu, A.-E.P.; Boldyryev, S. Thermodynamics-Based Process Sustainability Evaluation. Energies 2020, 13, 2132. [CrossRef]

152. Ehyaei, M.A.; Ahmadi, A.; Rosen, M.A. Energy, exergy, economic and advanced and extended exergy analyses of a wind turbine. Energy Convers. Manag. 2019, 183, 369-381. [CrossRef]

153. Quiroz-Ramírez, J.J.; Sánchez-Ramírez, E.; Segovia-Hernández, J.G. Energy, exergy and techno-economic analysis for biobutanol production: A multi-objective optimisation approach based on economic and environmental criteria. Clean Technol. Environ. Policy 2018, 20, 1663-1684. [CrossRef]

154. Balest, J.; Secco, L.; Pisani, E.; Garegnani, G. Municipal transitions: The social, energy, and spatial dynamics of sociotechnical change in South Tyrol, Italy. Energy Res. Soc. Sci. 2019, 54, 211-223. [CrossRef]

155. Garcia-Casals, X.; Ferroukhi, R.; Parajuli, B. Measuring the socioeconomic footprint of the energy transition. Energy Transit. 2019, 3, 105-118. [CrossRef]

156. Chandler, D.L. Battery Reuse Systems Could Be Profitable for Electric Vehicle Companies and Grid Scale Solar Operations. 2020. Available online: techxplore.com/news/2020-05-battery-reuse-profitable-electricvehicle.html (accessed on 2 June 2020).

157. Hanley, S. Nanotech Energy Claims its Graphene Lithium Battery Will Charge 18 Times Faster than Conventional Li-Ion Battery. Clean Technica. 2020. Available online: cleantechnica.com/2020/05/25/nanotechenergy-claims-its-graphene-lithium-battery-will-charge-18-times-faster-than-conventional-li-ion-battery/ (accessed on 2 June 2020).

158. EDF Environmental Defence Fund. Why Are Natural Gas Leaks a Problem. 2020. Available online: www.edf.org/climate/methanemaps/leaks-problem (accessed on 2 June 2020).

159. Exxon Mobil Corporation. Using New Technologies to Reduce Methane Emissions. 2020. Available online: energyfactor.exxonmobil.com/news/tech-reducing-methane-emissions/ (accessed on 2 June 2020).

160. Georgiou, M. The Role of AI Technology in Improving the Renewable Energy Sector. 2019. Available online: primary \%20goal\%20 of\%20AI,current $\% 20$ energy\%20consumption \%20and\%20demands (accessed on 4 June 2020).

161. Kosovic, B.; Haupt, S.E.; Adriaansen, D.; Alessandrini, S.; Wiener, G.; Delle Monache, L.; Liu, Y.; Linden, S.; Jensen, T.; Cheng, W.; et al. Comprehensive Wind Power Forecasting System Integrating Artificial Intelligence and Numerical Weather Prediction. Energies 2020, 13, 1372. [CrossRef] 
162. Ho, L.T.T.; Dubus, L.; De Felice, M.; Troccoli, A. Reconstruction of Multidecadal Country-Aggregated Hydro Power Generation in Europe Based on a Random Forest Model. Energies 2020, 13, 1786. [CrossRef]

163. Bandyk, M. Landfills Emerge as Promising Battery Storage Sites to Back Up Renewable Energy. 2020. Available online: www.utilitydive.com/news/landfills-promising-sites-battery-storage-solar-renewableenergy/578582/ (accessed on 2 June 2020). 